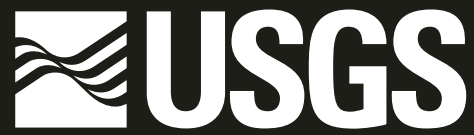

science for a changing world

X w. L enlo

Prepared in cooperation with the

Johnson County [Kans.] Stormwater Management Program

\title{
Preliminary Assessment of a Water-Quality Monitoring Program for Total Maximum Daily Loads in Johnson County, Kansas, January 2015 Through June 2016
} ,

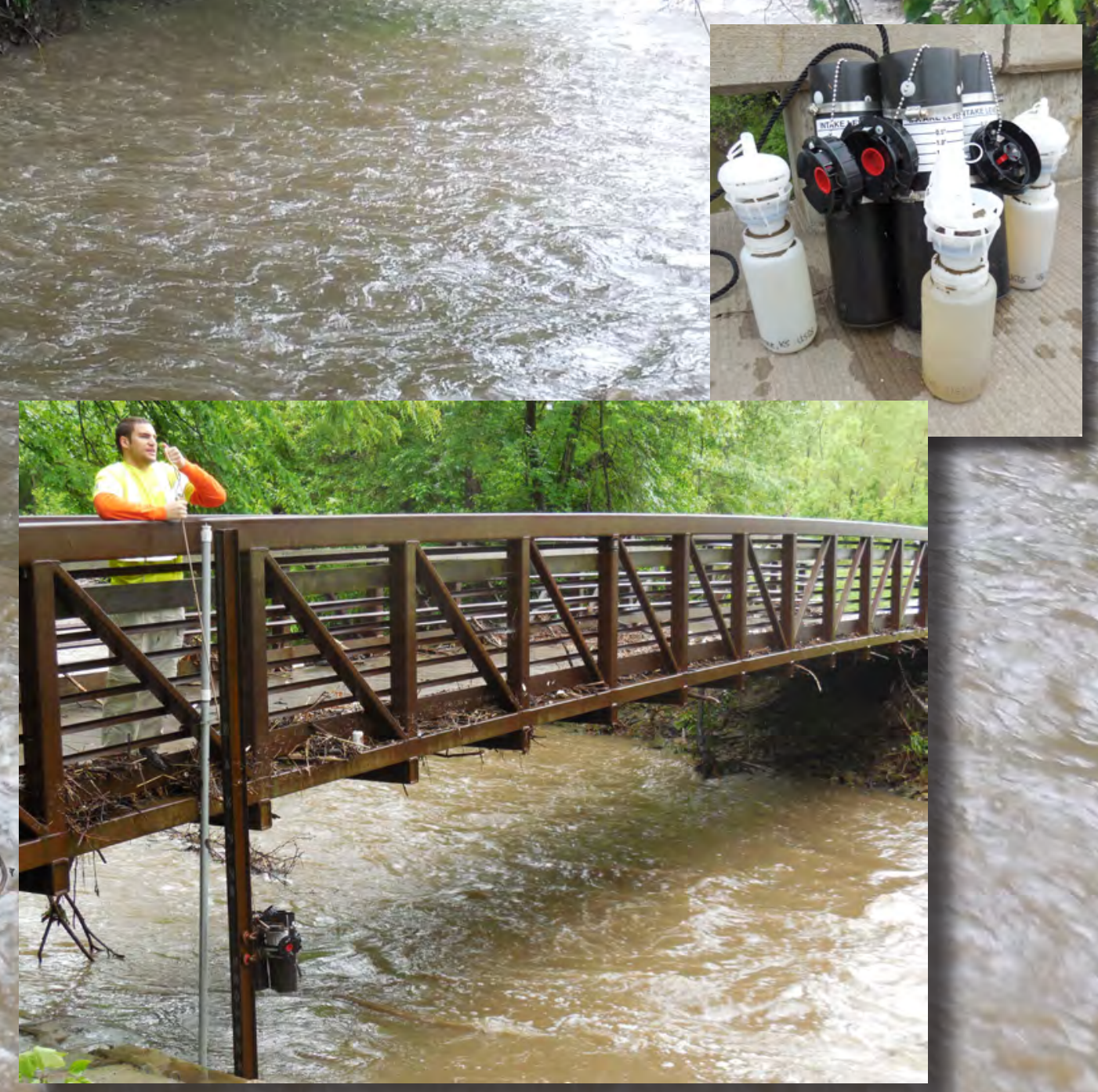

Scientific Knvestigations Report 2017-5089

U.S. Department of the Interior

U.S. Geologica) Survey 
Front cover. Background photograph: Storm runoff at the Tomahawk Creek near 111th Street, Johnson County, Kansas, U.S. Geological Survey monitoring site in May 2014; photograph by Teresa Rasmussen, U.S. Geological Survey.

Upper right: Storm samples collected from fixed-stage sampler in Johnson County, Kans.; photograph by Teresa Rasmussen, U.S. Geological Survey.

Lower left: Retrieving fixed-stage sampler during storm runoff at the Tomahawk Creek near 111th Street, Johnson County, Kans., U.S. Geological Survey monitoring site; photograph by Teresa Rasmussen, U.S. Geological Survey.

Back cover. Upper: Retrieving fixed-stage sampler from the Blue River near Stanley, Kans., U.S. Geological Survey streamgage; photograph by Teresa Rasmussen, U.S. Geological Survey. Lower right: Collecting base flow sample from the Turkey Creek at 75th Street, Overland Park, Kans., U.S. Geological Survey monitoring site; photograph by Ted Harris, U.S. Geological Survey. Lower left: Water-quality monitor deployed at the Mill Creek at Johnson Drive, Shawnee, Kans., U.S. Geological Survey streamgage; photograph by Chantelle Davis, U.S. Geological Survey. 


\section{Preliminary Assessment of a Water-Quality Monitoring Program for Total Maximum Daily Loads in Johnson County, Kansas, January 2015 Through June 2016}

By Teresa J. Rasmussen and Chelsea R. Paxson

Prepared in cooperation with the

Johnson County [Kans.] Stormwater Management Program

Scientific Investigations Report 2017-5089 


\title{
U.S. Department of the Interior \\ RYAN K. ZINKE, Secretary
}

\section{U.S. Geological Survey William H. Werkheiser, Acting Director}

\author{
U.S. Geological Survey, Reston, Virginia: 2017
}

For more information on the USGS - the Federal source for science about the Earth, its natural and living resources, natural hazards, and the environment-visit http://www.usgs.gov/ or call 1-888-ASK-USGS.

For an overview of USGS information products, including maps, imagery, and publications, visit http://store.usgs.gov/.

Any use of trade, firm, or product names is for descriptive purposes only and does not imply endorsement by the U.S. Government.

Although this information product, for the most part, is in the public domain, it also may contain copyrighted materials as noted in the text. Permission to reproduce copyrighted items must be secured from the copyright owner.

Suggested citation:

Rasmussen, T.J., and Paxson, C.R., 2017, Preliminary assessment of a water-quality monitoring program for total maximum daily loads in Johnson County, Kansas, January 2015 through June 2016: U.S. Geological Survey Scientific Investigations Report 2017-5089, 20 p., https://doi.org/10.3133/sir20175089.

ISSN 2328-0328 (online) 


\section{Acknowledgments}

The authors wish to thank Lee Kellenberger and Heather Schmidt with the Johnson County

Stormwater Management Program for technical assistance and information related to

stormwater management in Johnson County. The help of Tony Holt and the staff of the Johnson

County Environmental Laboratory in sample analyses is greatly appreciated. The authors extend

their appreciation to Bill Maasen and the employees of the Johnson County Park and Recreation

District for facilitating convenient access to several stream sites. 



\section{Contents}

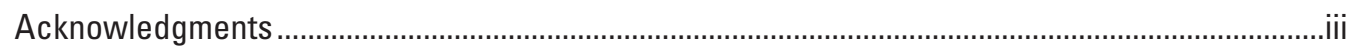

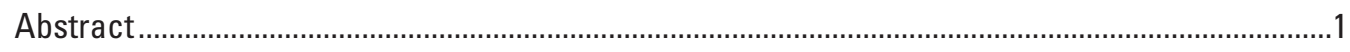

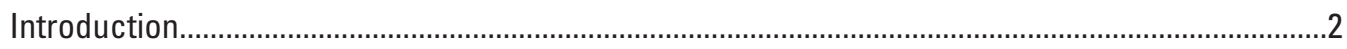

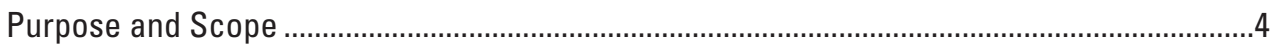

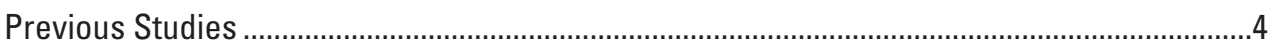

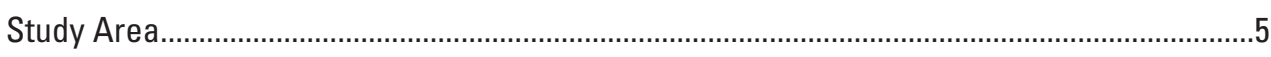

Methods

Discrete Data Collection ..................................................................................................

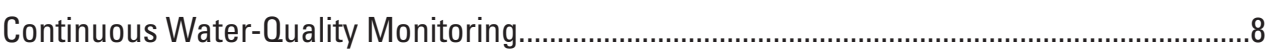

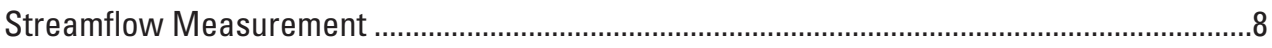

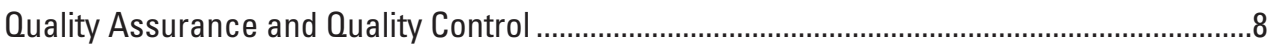

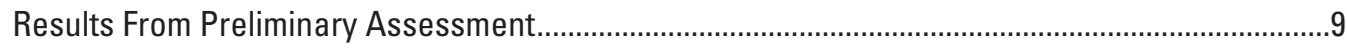

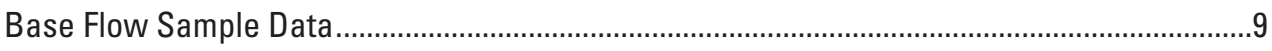

Stormwater Sample Data ................................................................................................. 11

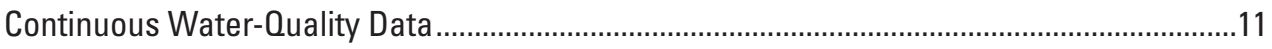

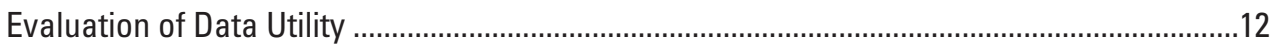

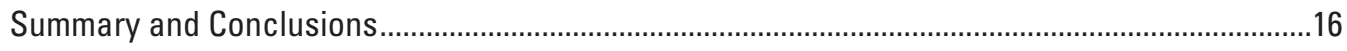

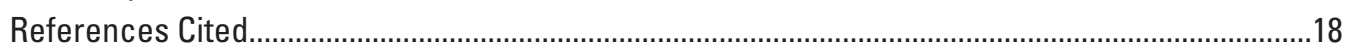

\section{Figures}

1. Map showing the study area and the Kansas City metropolitan area in Johnson County, Kansas....

2. Photographs of sampling and monitoring stations used to evaluate a water-quality monitoring plan in Johnson County, Kansas: $A$, passive sampler, $B$, passive sampler carriage, $C$, passive sampler carriage installation at pylon of bridge, $D$, continuous water-quality monitor installation at Mill Creek, E, YSI Inc. EXO2 multiparameter sonde, and $F$, Hach Co. Nitratax nitrate sensor..

3. Graph showing total nitrogen concentrations in base flow and storm runoff samples from 27 sites in Johnson County, Kansas, from January 2015 to June 2016.....10

4. Graph showing total phosphorus concentrations in base flow and storm runoff samples from 27 sites in Johnson County, Kansas, from January 2015 to June 2016.....10

5. Graph showing Escherichia coli densities in base flow and storm runoff samples from 27 sites in Johnson County, Kansas, from January 2015 to June 2016.

6. Graph showing total suspended solids concentrations in base flow and storm runoff samples from 27 sites in Johnson County, Kansas, from January 2015 to June 2016 .

7. Graph showing continuous and discrete nitrate plus nitrite data from the monitoring site on Mill Creek at Johnson Drive, Shawnee, in Johnson County, Kansas, from January 2015 to June 2016 


\section{Tables}

1. Municipalities, water bodies, and pollutants with total maximum daily loads for streams and a lake in Johnson County, Kansas...

2. Water-quality monitoring sites in Johnson County, Kansas...............................................6

3. Relative percentage difference summary for replicate sample pairs ................................9

4. Summary of continuous water-quality data from Mill Creek at Johnson Drive, Shawnee, Johnson County, Kansas, January 2015-June 2016

5. Summary of valuable and limiting attributes of the current water-quality monitoring program in Johnson County, Kansas, and possible approaches for making improvements

\section{Conversion Factors}

U.S. customary units to International System of Units

\begin{tabular}{lll}
\hline \multicolumn{1}{c}{ Multiply } & \multicolumn{1}{c}{ By } & \multicolumn{1}{c}{ To obtain } \\
\hline inch (in.) & 2.54 & centimeter $(\mathrm{cm})$ \\
foot $(\mathrm{ft})$ & 0.3048 & meter $(\mathrm{m})$ \\
square mile $\left(\mathrm{mi}^{2}\right)$ & 2.590 & square kilometer $\left(\mathrm{km}^{2}\right)$ \\
cubic foot per second $\left(\mathrm{ft}^{3} / \mathrm{s}\right)$ & 0.02832 & cubic meter per second $\left(\mathrm{m}^{3} / \mathrm{s}\right)$ \\
ton, short $(2,000 \mathrm{lb})$ & 0.9072 & metric ton $(\mathrm{t})$ \\
\hline
\end{tabular}

\section{Datum}

Horizontal coordinate information is referenced to the North American Datum of 1983 (NAD 83). Vertical coordinate information is referenced to the North American Vertical Datum of 1988 (NAVD 88).

Elevation, as used in this report, refers to distance above the vertical datum.

\section{Abbreviations}

$\begin{array}{ll}\text { BMP } & \text { best management practice } \\ \text { EWI } & \text { equal width increment } \\ \text { JCSMP } & \text { Johnson County Stormwater Management Program } \\ \text { KDHE } & \text { Kansas Department of Health and Environment } \\ \text { MS4 } & \text { municipal separate storm sewer system } \\ \text { NPDES } & \text { National Pollutant Discharge Elimination System } \\ \text { TMDL } & \text { total maximum daily load } \\ \text { USGS } & \text { U.S. Geological Survey }\end{array}$




\title{
Preliminary Assessment of a Water-Quality Monitoring Program for Total Maximum Daily Loads in Johnson County, Kansas, January 2015 Through June 2016
}

\author{
By Teresa J. Rasmussen and Chelsea R. Paxson
}

\section{Abstract}

Municipalities in Johnson County in northeastern Kansas are required to implement stormwater management programs to reduce pollutant discharges, protect water quality, and comply with applicable water-quality regulations in accordance with National Pollutant Discharge Elimination System permits for stormwater discharge. To this end, municipalities collect grab samples at streams entering and leaving their jurisdiction to determine levels of excessive nutrients, sediment, and fecal bacteria to characterize pollutants and understand the factors affecting them.

In 2014, the U.S. Geological Survey and the Johnson County Stormwater Management Program, with input from the Kansas Department of Health and Environment, initiated a 5-year monitoring program to satisfy minimum sampling requirements for each municipality as described by new stormwater permits issued to Johnson County municipalities. The purpose of this report is to provide a preliminary assessment of the monitoring program. The monitoring program is described, a preliminary assessment of the monitoring program design is provided using water-quality data collected during the first 2 years of the program, and the ability of the current monitoring network and sampling plan to provide data sufficient to quantify improvements in water quality resulting from implemented and planned best management practices is evaluated. The information in this initial report may be used to evaluate changes in data collection methods while data collection is still ongoing that may lead to improved data utility.

Discrete water-quality samples were collected at 27 sites and analyzed for nutrients, Escherichia coli (E. coli) bacteria, total suspended solids, and suspended-sediment concentration. In addition, continuous water-quality data (water temperature, $\mathrm{pH}$, dissolved oxygen, specific conductance, turbidity, and nitrate plus nitrite) were collected at one site to characterize variability and provide a basis for comparison to discrete data. Base flow samples indicated that point sources are likely affecting nutrient concentrations and E. coli bacteria densities at several sites. Concentrations of all analytes in storm runoff samples were characterized by substantial variability among sites and samples. About one-half of the sites, representing different watersheds, had storm runoff samples with nitrogen concentrations greater than 10 milligrams per liter. About one-third of the sites, representing different watersheds, had storm runoff samples with total phosphorus concentrations greater than 3 milligrams per liter. Six sites had samples with E. coli densities greater than 100,000 colonies per 100 milliliters of water. Total suspended solids concentrations of about 12,000 milligrams per liter or greater occurred in samples from three sites.

Data collected for this monitoring program may be useful for some general assessment purposes but may also be limited in potential to fully inform stormwater management activities. Valuable attributes of the monitoring program design included incorporating many sites across the county for comparisons among watersheds and municipalities, using fixed-stage samplers to collect multiple samples during single events, collection of base flow samples in addition to storm samples to isolate possible point sources from stormwater sources, and use of continuous monitors to characterize variability. Limiting attributes of the monitoring program design included location of monitoring sites along municipal boundaries to satisfy permit requirements rather than using watershed-based criteria such as locations of tributaries, potential pollutant sources, and implemented management practices. Additional limiting attributes include having a large number of widespread sampling locations, which presented logistical challenges for predicting localized rainfall and collecting and analyzing samples during short timeframes associated with storms, and collecting storm samples at fixedstage elevations only during the rising limb of storms, which does not characterize conditions over the storm hydrograph. The small number of samples collected per site resulted in a sample size too small to be representative of site conditions, including seasonal and hydrologic variability, and insufficient for meaningful statistical analysis or site-specific modeling.

Several measures could be taken to improve data utility and include redesigning the monitoring network according to watershed characteristics, incorporating a nested design in which data are collected at different scales (watershed, subwatershed, and best management practices), increasing sampling frequency, and combining different methods to allow for 
flexibility to focus on areas and conditions of particular interest. A monitoring design that would facilitate most of these improvements would be to focus efforts on a limited number of watersheds for several years, then cycle to the next set of watersheds for several years, eventually returning to previously monitored watersheds to document changes.

Redesign of the water-quality monitoring program requires considerable effort and commitment from municipalities of Johnson County. However, the long-term benefit likely is a monitoring program that results in improved stream conditions and more effective management practices and efficient expenditure of resources.

\section{Introduction}

In response to new stormwater discharge permits issued to municipalities in Johnson County in 2014, the U.S. Geological Survey (USGS) and the Johnson County Stormwater Management Program (JCSMP) developed a program to help municipalities meet water-quality monitoring requirements. Municipal stormwater discharges are regulated by provisions described in the Clean Water Act from 1972 (Public Law 92-500; 86 Stat. 816) to protect the Nation's water resources from harmful pollutants. Kansas municipalities are required to obtain stormwater discharge permits from the Kansas Department of Health and Environment (KDHE) in compliance with the U.S. Environmental Protection Agency's National Pollutant Discharge Elimination System (NPDES; https://www.epa.gov/npdes) to ensure compliance with State and Federal regulations for protecting water quality (Kansas Department of Health and Environment, 2013). General stormwater permits with similar basic compliance requirements have been issued to municipalities in Johnson County with small municipal separate storm sewer systems (MS4s) (Kansas Department of Health and Environment, 2016b). In the 2014 revision of the permits, municipalities were required to implement stormwater management programs to reduce discharges of pollutants, protect water quality, and satisfy applicable water-quality regulations. In addition, municipalities are required by their permits to monitor water quality as dictated by KDHE-designated total maximum daily loads (TMDLs). Stormwater discharge permits require municipalities to install pollutant source controls and best management practices (BMPs) and monitor the effectiveness of those efforts in achieving goals for pollution reduction (Kansas Department of Health and Environment, 2016b).

A TMDL is the maximum amount of a pollutant a waterbody can receive while still meeting water-quality standards (Kansas Department of Health and Environment, 2016a). States are required by section 303(d) of the Clean Water Act to identify water bodies that are water-quality impaired and the pollutants causing the impairments. TMDLs are developed for each pollutant to determine reduction targets and implementation plans. Water-quality impairments in Johnson
County primarily are caused by excessive nutrients, sediment, and fecal bacteria (Kansas Department of Health and Environment, 2012).

Johnson County in northeastern Kansas is part of the Kansas City metropolitan area (fig. 1). It is largely suburban, with 20 municipalities sharing all or parts of 22 watersheds (HUC-14; Seaber and others, 1987). Thirteen streams and one lake in the county have designated TMDLs with monitoring requirements (table 1; Kansas Department of Health and Environment, 2014). Thus, a coordinated effort among municipalities and Johnson County is a practical approach to meeting compliance requirements. In 2016, Johnson County developed a new strategic plan for stormwater management (Black and Veatch Holding Company, 2016). Development of the new plan was driven by a shift in the practice of managing stormwater that had been primarily focused on flood control to also include water quality issues, by evolving regulations, and by a trend toward integrated water-resource planning. One outcome of the new strategic direction was a plan for stormwater management to take place on a watershed-level basis with coordination among municipalities.

Monitoring required by stormwater permits is intended to assess improvements in the targeted water body resulting from BMPs implemented under stormwater management programs (Kansas Department of Health and Environment, 2013). At a minimum, municipalities are required to collect grab samples during the rising stages of four runoff events annually at stream locations entering and leaving their jurisdictional areas. Qualifying runoffs are those that result from at least $0.5 \mathrm{inch}$ of precipitation during a 24-hour period. Urban stream systems and pollutant sources are complex (Paul and Meyer, 2001; Coles and others, 2012), and water quality can be highly variable and change rapidly during storm runoff. The ability to characterize stormwater quality and effectiveness of BMPs on the basis of such a limited dataset is questionable because the dataset likely is not representative of site variability and conditions, is insufficient for meaningful statistical analysis, and could result in misleading data interpretations by stakeholders and poor information for decision-making related to TMDLs and future BMP effectiveness. Collection of additional waterquality data at selected monitoring sites using more robust sampling program design and methods could enable a better understanding of the limitations of the minimum-required approach. In addition to documenting pollutant occurrence, a successful municipal stormwater monitoring program could provide adequate information to characterize pollutants and understand the factors affecting them so that effective management practices can be implemented.

In 2014, a 5-year monitoring program was initiated by the USGS in cooperation with the JCSMP. The monitoring program was intended to meet new stormwater monitoring requirements for municipalities in Johnson County according to sampling frequency and conditions described in stormwater permits and to evaluate the utility of different types of data in assessing improvements in water quality. Results from the 5-year study are intended for use in the evaluation 


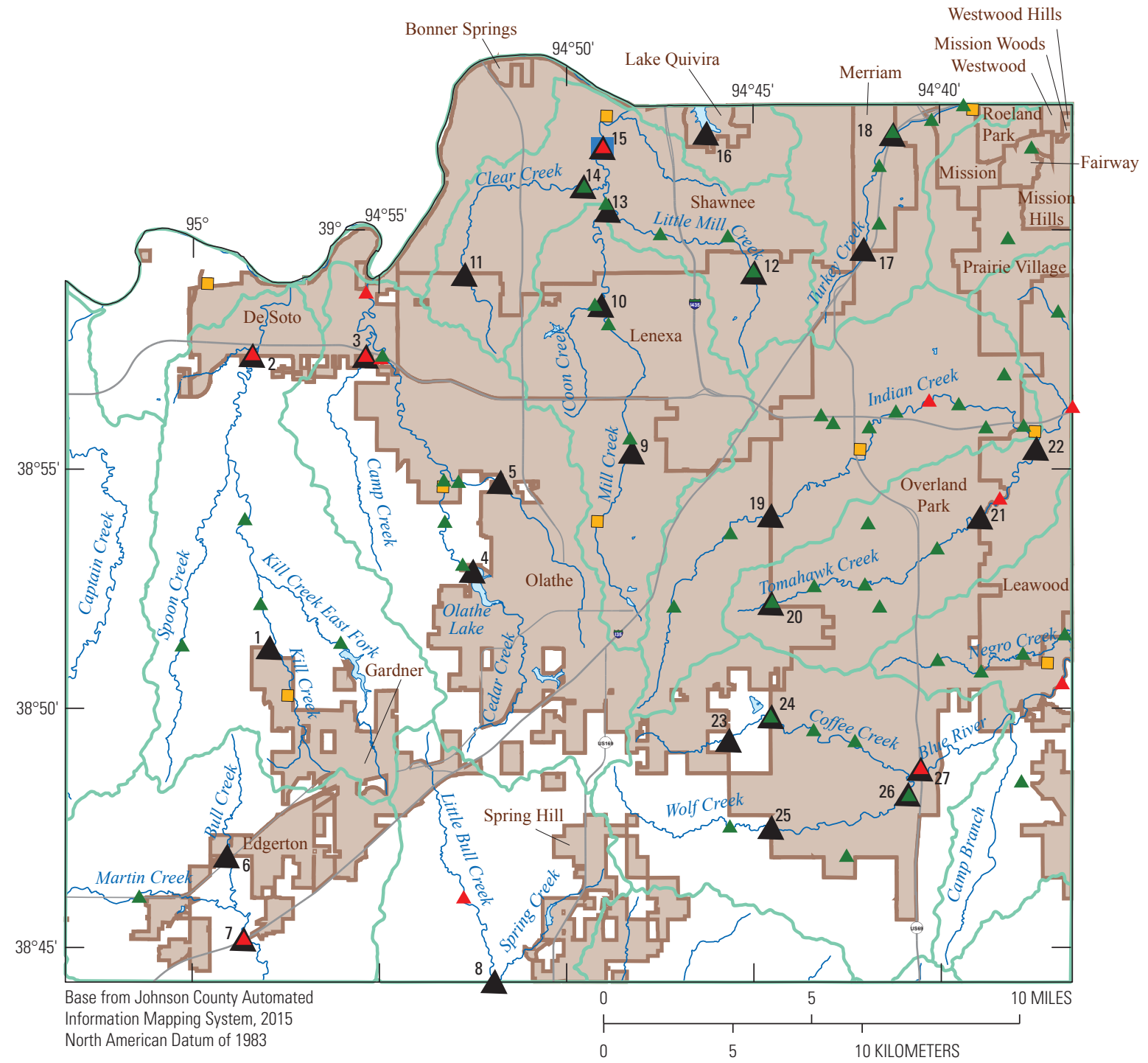

EXPLANATION

Kansas City metropolitan area

Watershed boundary within Johnson County

Municipal boundary

U.S. Geological Survey streamgage

- StormWatch gage site

15 Continuous water-quality monitoring site and identifier-Listed in table 2

$\Delta^{12}$ Total maximum daily load monitoring site and identifier-Listed in table 2

$\square \quad$ Wastewater treatment facility

Figure 1. The study area and the Kansas City metropolitan area in Johnson County, Kansas. 
Table 1. Municipalities, water bodies, and pollutants with total maximum daily loads for streams and a lake in Johnson County, Kansas.

\begin{tabular}{lll}
\hline \multicolumn{1}{c}{ Municipality } & \multicolumn{1}{c}{ Water body } & Pollutant causing water-quality impairment \\
\hline Leawood & Tomahawk Creek & Bacteria and nutrients \\
Lenexa & Little Mill Creek & Sediment, bacteria, and nutrients \\
& Clear Creek & Sediment, bacteria, and nutrients \\
Johnson County (unincorporated) & Camp Creek & Sediment, bacteria, and nutrients \\
& Kill Creek & Sediment, bacteria, and nutrients \\
& Big Bull Creek & Nutrients \\
& Little Bull Creek & Nutrients \\
& Coffee Creek & Sediment, bacteria, and nutrients \\
& Wolf Creek & Sediment, bacteria, and nutrients \\
Merriam & Turkey Creek & Sediment, bacteria, and nutrients \\
Overland Park & Coffee Creek & Sediment, bacteria, and nutrients \\
& Wolf Creek & Sediment, bacteria, and nutrients \\
& Tomahawk Creek & Bacteria and nutrients \\
\hline Olathe & Mill Creek & Sediment, bacteria, and nutrients \\
& Little Cedar Creek & Bacteria and nutrients \\
& Indian Creek & Bacteria and nutrients \\
& Olathe Lake & Nutrients \\
\hline Shawnee & Little Mill Creek & Sediment, bacteria, and nutrients \\
& Clear Creek & Sediment, bacteria, and nutrients \\
\hline
\end{tabular}

of water quality relative to TMDL and BMP goals to evaluate comparability of data collected using different methods, qualify interpretation of data on the basis of different collection methods, and modify data collection methods in future monitoring plans.

\section{Purpose and Scope}

The purpose of this report is to provide a preliminary assessment of the 5-year TMDL monitoring program implemented by the USGS in cooperation with the JCSMP in Johnson County. The monitoring program is described, a preliminary assessment of the monitoring program design is provided using water-quality data collected from January 2015 through June 2016, and the ability of the current monitoring network and sampling plan to provide data sufficient to quantify improvements in water quality resulting from implemented and planned best management practices is evaluated. Information evaluated for the preliminary assessment will be used to suggest changes in the monitoring program design in order to improve data utility while data collection is still ongoing. Discrete water-quality samples were collected at 27 sites and analyzed for nutrients, Escherichia coli (E. coli) bacteria, total suspended solids, and suspended-sediment concentrations. In addition, continuous water-quality data (water temperature, $\mathrm{pH}$, dissolved oxygen, specific conductance, turbidity, and nitrate plus nitrite) were collected at one site to characterize variability and provide a basis for comparison to discrete data.

\section{Previous Studies}

Water quality in Johnson County was evaluated in a number of previous USGS studies (Lee and others, 2005, 2010; Wilkison and others, 2009; Graham and others, 2010, 2014; Rasmussen and others, 2012, 2014). Lee and others (2005) described effects of nonpoint and point contaminant sources on streams on the basis of data collected during 2002-04. Results indicated that, during base flow, discharge from wastewater treatment facilities composed more than onehalf of streamflow at sampling sites located downstream from wastewater discharges. In addition, during below-normal and normal streamflows, concentrations of nutrients commonly were an order of magnitude higher at sites located downstream from wastewater discharges compared with sites unaffected by wastewater.

General stream quality was characterized on the basis of the quality of aquatic biological communities from 2002-10 (Rasmussen and others, 2012). Biological stream quality generally reflected a gradient in urban land use, with the least disturbed streams being in rural areas of the county. Nineteen percent of sites in 2010 were fully supporting of aquatic life, according to the four metrics used by the KDHE to categorize 
sites. Environmental variables that consistently were highly negatively correlated with stream health were percent impervious area, density of stormwater outfalls adjacent to streams, specific conductance of water, and concentrations of polycyclic aromatic hydrocarbons in streambed sediment.

The effects of wastewater on receiving streams had been assessed for the Blue River (Graham and others, 2010) and Indian Creek (Graham and others, 2014). In both studies, nutrient concentrations downstream from wastewater discharges decreased after upgrades to treatment facilities but were still elevated compared with concentrations upstream from discharges. An evaluation of stream metabolism indicated effects of wastewater did not cause persistent declines in overall stream health.

Discrete and continuous water-quality data were used to develop regression models for computing continuous concentrations and loads of suspended sediment, dissolved solids, major ions, nutrients, and indicator bacteria in five principal streams during 2003-11 (Rasmussen and Gatotho, 2014). Concentrations of suspended sediment, chloride, and fecal-bacteria indicators generally were higher in urban watersheds than in nonurban watersheds and were substantially higher during periods of increased streamflow than in periods of base flow.

\section{Study Area}

Johnson County, part of the Kansas City metropolitan area that shares a State border with Missouri, is an area of 477 square miles $\left(\mathrm{mi}^{2}\right)$ in northeastern Kansas. Land use ranges from rural in the western part of the county to highly urban in the northeastern part of the county. A water-quality monitoring network consisting of 25 stream sites and 2 lake sites has been deployed across Johnson County (fig. 1; table 2). Network sites were selected to bracket municipal boundaries and use established sampling sites from previous USGS studies for historical context. Site access, conditions, and suitability for sampling also were considered. One site (Indian Creek at Pflumm Road; fig. 1, site 19) was removed from the network after the first year of data collection when that stream segment was not included in the final TMDL listing as was expected. Two sites (Kill Creek at 151st Street and Quivira Lake near Lake Quivira; fig. 1, sites 1 and 16) were added after the first year of data collection. All stream sites are located at road or pedestrian bridges.

\section{Methods}

The monitoring program was designed by the USGS and the JCSMP with input from the KDHE primarily to satisfy minimum sampling requirements for each municipality as described in stormwater permits. Emphasis for site selection was placed on municipal boundaries because stormwater permits are determined according to municipality and included TMDLs that apply to stream segments within municipal boundaries. Water-quality data, including nutrients, E. coli bacteria, total suspended solids, and suspended-sediment concentration, were collected at all 27 sites in the monitoring network. Discrete samples using passive samplers or grab samples were collected at all sites. USGS protocols and procedures as described in the "National Field Manual for the Collection of Water-Quality Data" (U.S. Geological Survey, variously dated) were followed for cleaning equipment, collecting field measurements and samples, and processing samples.

Some additional data were collected to help describe possible limitations of the primary data required by permits. Method comparison data were collected at the sites at Tomahawk Creek near 111th Street (fig. 1, site 22), Wolf Creek at 179th Street (fig. 1, site 26), and Mill Creek at Johnson Drive (fig. 1, site 15). Method comparison data consisted of passive, grab, and equal-width-increment (EWI) samples collected nearly concurrently. The most comprehensive data collection approach occurred at Mill Creek at Johnson Drive (fig. 1, site 15) where continuous water-quality data were collected in addition to the passive, grab, and EWI samples. A preliminary evaluation of methods comparison data is not included in this report because data collection was not complete and the dataset of the three sites is too small to provide meaningful information.

Annual loads from discrete samples were calculated by multiplying the average concentration by annual mean streamflow during 2015 (calculated from instantaneous streamflow values) and a conversion factor. Loads from continuous data were calculated by summing unit values of instantaneous load (concentration multiplied by streamflow) over the period of interest.

\section{Discrete Data Collection}

Discrete water-quality samples were collected using passive, grab, and EWI sampling (U.S. Geological Survey, 2006). The standard method employed for this study was passive sampling. Passive samplers were installed at stream sites to collect a minimum of four water samples annually from each site during the rising limb of different storms. Nalgene ${ }^{\mathrm{TM}}$ storm water samplers (fig. $2 A$ ) were deployed in mounting tubes attached to a carriage that was equipped with trolley wheels (fig. $2 B$ ) that allowed the carriage to be lowered down an I-beam extending vertically from the bridge deck to the streambed (fig. 2C). The sampler carriage rested at a fixed-stage elevation that became submerged as stream stage increased. The sampler bottles (fig. $2 A$ ) filled as water flowed through the collection funnel and stopped filling when the floating ball valve blocked the opening and prevented comingling of sample water with ambient water. Three bottles were deployed simultaneously in the carriage (fig. $2 B$ ) to collect an adequate volume of sample water. Sample bottles were retrieved by raising the carriage back up to the bridge deck (fig. 2D). The samplers were set at elevations expected to capture runoff from 24-hour rainfalls resulting in at least 
Table 2. Water-quality monitoring sites in Johnson County, Kansas.

[ID, identification number; mi² $^{2}$, square miles; KS, Kansas; Co, County]

\begin{tabular}{|c|c|c|c|}
\hline $\begin{array}{l}\text { Site number } \\
\text { (fig. 1) }\end{array}$ & Station ID & Station name & $\begin{array}{l}\text { Drainage area, } \\
\text { in } \mathrm{mi}^{2}\end{array}$ \\
\hline 1 & 385118094575700 & Kill Creek at 151st Street near Gardner, KS & 5.76 \\
\hline 2 & 06892360 & Kill Creek at 95th Street near DeSoto, KS & 53.4 \\
\hline 3 & 06892494 & Camp Creek at 95th Street near DeSoto, KS & 9.00 \\
\hline 4 & 06892450 & Olathe Lake near Olathe, KS & 17.0 \\
\hline 5 & 385445094514700 & Little Cedar Creek at 119th Street, Olathe, KS & 6.85 \\
\hline 6 & 384656094590400 & Big Bull Creek at 191st Street, Edgerton, KS & 4.91 \\
\hline 7 & 06914950 & Big Bull Creek near Edgerton, KS (I-35) & 28.7 \\
\hline 8 & 384419094515600 & Little Bull Creek near 215th Street, Johnson Co, KS & 16.6 \\
\hline 9 & 385523094481500 & Mill Creek near 114th Street, Olathe, KS & 8.47 \\
\hline 10 & 385827094490500 & Mill Creek at 85th Street, Lenexa, KS & 25.7 \\
\hline 11 & 385906094524400 & Clear Creek at 79th Street, Lenexa, KS & 2.68 \\
\hline 12 & 385908094445900 & Little Mill Creek at 79th Street, Lenexa, KS & 4.44 \\
\hline 13 & 390026094485300 & Little Mill Creek near Midland Road, Shawnee, KS & 12.9 \\
\hline 14 & 390056094493200 & Clear Creek at Woodland Road, Shawnee, KS & 10.9 \\
\hline 15 & 06892513 & Mill Creek at Johnson Drive, Shawnee, KS & 58.1 \\
\hline 16 & 390242094461500 & Quivira Lake near Lake Quivira, KS & 4.52 \\
\hline 17 & 385937094420300 & Turkey Creek near 75th Street, Overland Park, KS & 4.49 \\
\hline 18 & 390201094411500 & Turkey Creek at Antioch, Overland Park, KS & 14.3 \\
\hline 19 & 385403094443200 & Indian Creek at Pflumm Rd near Overland Park, KS & 10.9 \\
\hline 20 & 385213094443200 & Tomahawk Creek at Pflumm Road, Overland Park, KS & 1.65 \\
\hline 21 & 385401094385600 & Tomahawk Creek at Nall Avenue, Leawood, KS & 18.1 \\
\hline 22 & 385539094372100 & Tomahawk Creek near 111th Street, Johnson Co, KS & 23.4 \\
\hline 23 & 384922094454000 & Coffee Creek at Lackman Road, Olathe, KS & 3.57 \\
\hline 24 & 384951094443200 & Coffee Creek at Pflumm Road, Johnson Co, KS & 7.55 \\
\hline 25 & 384732094443200 & Wolf Creek at Pflumm Road, Johnson Co, KS & 10.0 \\
\hline 26 & 384813094405300 & Wolf Creek at 179th Street, Overland Park, KS & 28.7 \\
\hline 27 & 06893080 & Blue River near Stanley, KS & 46.0 \\
\hline
\end{tabular}

0.5 inches of precipitation. Appropriate elevations were determined by evaluating historic rainfall and streamflow data from StormWatch (Overland Park, 2017) and nearby existing USGS streamgages (fig. 1). Fixed markers were placed at each site to ensure consistent sampler elevation deployment. By deploying passive samplers at specified stream stages, samples were reliably collected on the rising limb and during similar streamflow conditions. Passive sampler bottles were retrieved and delivered to the laboratory as soon as practicable to ensure preservation or analysis within 24 hours of filling (American Public Health Association and others, 1995).

Grab sampling was also used to collect discrete samples. Grab samples, which are collected by dipping open containers into a stream or lake at a single point and time, often are the primary collection method used in municipal monitoring programs because of the relative ease and low cost of collection.
Grab samples were collected during base flow sampling to capture rising limbs during runoffs and for additional data collection comparisons at selected sites. To document water quality during base flow conditions, sampling at all sites was surveyed annually (in 2015 and 2016) in March. The data from the annual surveys will help determine baseline constituent concentrations to distinguish between base flow and storm conditions. In addition to discrete grab samples collected during storms, grab samples were collected at Olathe Lake (fig. 1, site 4) and Quivira Lake (fig. 1, site 16) 10 to 14 days after a qualifying rainfall. Only one lake sample was collected per event.

Lastly, EWI collection methods (U.S. Geological Survey, 2006) were used at selected sites to collect discrete data samples. EWI collection provides isokinetic samples that are representative of the entire stream cross section. For this study, 

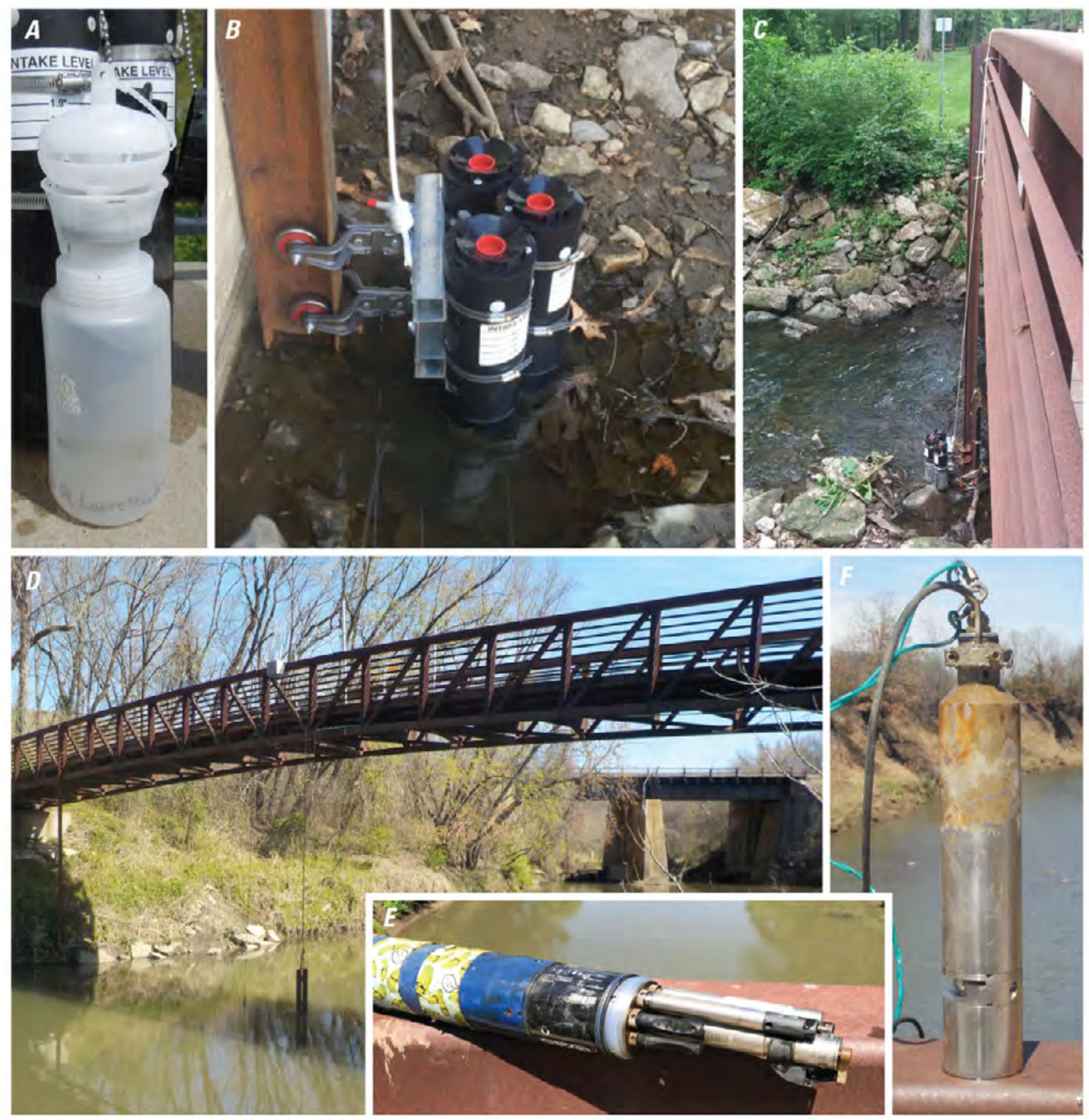

Figure 2. Sampling and monitoring stations used to evaluate a water-quality monitoring plan in Johnson County, Kansas: $A$, passive sampler, $B$, passive sampler carriage, $C$, passive sampler carriage installation at pylon of bridge, $D$, continuous water-quality monitor installation at Mill Creek (fig. 1, site 15), $E$, YSI Inc. EX02 multiparameter sonde, and $F$, Hach Co. Nitratax nitrate sensor.

EWI samples were collected to compare data collection methods and to develop surrogate regression models (for example, Rasmussen and others, 2008, and Rasmussen and Gatotho, 2014) for computing constituents of interest in real time using continuously monitored data. Only samples collected using EWI methods will be used to develop models. Samples collected for the purpose of method comparison, both grab and EWI, were collected as near in time as possible (within 15 minutes) to the samples collected with passive samplers.

Targeted analytes for all sites were nutrients (dissolved phosphorus, total phosphorus, orthophosphate, nitrate plus nitrite, nitrite, ammonia, and ammonia plus organic nitrogen),
E. coli bacteria, and total suspended solids because they commonly were included in the 303(d) list of pollutants causing waterbodies to become impaired in Johnson County (Kansas Department of Health and Environment, 2012) and require monitoring according to permits. Suspended-sediment concentrations were added to the analysis because they are generally considered to be more reliable than total suspended solids for quantifying solids in natural water (Gray and others, 2000). Although all sites were not listed as impaired for all of these analytes (table 1), all the analytes were routinely included for all sites to provide a more complete and consistent evaluation of pollutant occurrence and to simplify sampling methods. 
Chlorophyll $\alpha$ and pheophytin $\alpha$ samples were collected at Olathe Lake and Quivira Lake because that was an additional permit requirement for lake sites.

Analyses of concentrations of nutrients and E. coli were conducted by the Johnson County Environmental Laboratory in Olathe, Kans., in accordance with standard methods (American Public Health Association and others, 1995).

E. coli concentrations were analyzed using Idexx Laboratories Inc. Colilert enzyme substrate most probable number methods. Nutrient analyses also were completed by the USGS National Water Quality Laboratory (NWQL) in Lakewood, Colorado, according to standard methods (American Public Health Association and others, 1995; Fishman and Friedman, 1989; Patton and Truitt, 1992, 2000; Fishman, 1993; Patton and Kryskalla, 2011). For samples that had nutrients analyzed by the NWQL, E. coli concentrations were analyzed by the USGS Kansas Water Science Center in Lawrence, Kans., using membrane filtration according to methods described in Myers and others (2014). Suspended-sediment samples were analyzed by the USGS Iowa Sediment Laboratory in Iowa City, Iowa, in accordance with Guy (1969). Chlorophyll $\alpha$ and pheophytin $\alpha$ samples collected from Olathe Lake and Quivira Lake were analyzed by the NWQL according to methods in Arar and Collins (1997). Data were routinely compiled and reviewed and periodically evaluated in accordance with USGS Kansas Water Science Center procedures (Rasmussen and others, 2014). Data were entered in the USGS National Water Information System database (U.S. Geological Survey, 2016b).

\section{Continuous Water-Quality Monitoring}

A continuous, real-time water-quality monitor and a nitrate monitor were deployed at Mill Creek at Johnson Drive in Shawnee, Kans. (figs. 1 and 2D; table 2), which was an existing streamgage and former monitoring site, to evaluate water-quality variability and pollutant loading. Continuous, real-time monitors provide water-quality information during storm runoff when conditions are changing rapidly. Surrogate models that define relations between in-place monitoring data and laboratory-analyzed data make it possible to provide continuous real-time computations for particular constituents of concern. The water-quality monitor was installed in October 2014, and the nitrate monitor was installed in November 2014. The water-quality monitor is a YSI Inc. EXO2 multiparameter sonde that measures water temperature, $\mathrm{pH}$, dissolved oxygen, specific conductance, and turbidity (fig. 2E; YSI Inc., 2014). The nitrate monitor is a Hach Co. Nitratax nitrate sensor (fig. $2 F$ ) that measures nitrate plus nitrite. Nitrite is generally considered negligible in most surface waters (Pellerin and others, 2013) and in Johnson County streams (Rasmussen and others, 2012), so the Nitratax primarily measured nitrate. Measurements were recorded every 15 minutes and transmitted hourly.

Each monitor was operated in accordance with standard USGS procedures (Wagner and others, 2006; Pellerin and others, 2013; Bennett and others, 2014). Data from the Nitratax sensor and other continuous water-quality-monitor data are available in near real-time at U.S. Geological Survey (2016a, 2016b).

\section{Streamflow Measurement}

Streamflow data corresponding with each sample originated from several sources. Within the monitoring network established for this phase of the study, five sites (fig. 1; table 2) have preexisting USGS streamgages: Big Bull Creek near Edgerton (bridge on Interstate I-35; site 7), Blue River near Stanley (bridge on U.S. Route 69; site 27), Camp Creek at 95th Street near DeSoto (site 3), Kill Creek at 95th Street near DeSoto (site 2), and Mill Creek at Johnson Drive in Shawnee (site 15). These USGS streamgages collect data at 15-minute intervals and transmit data hourly. Real-time data are available at U.S. Geological Survey (2016a). Streamgage sites were maintained and operated according to USGS methods in Turnipseed and Sauer (2010) and Painter and Loving (2015). For all other sites, stage data were recorded during sampling events with Onset Computer Corp. Hobo level loggers deployed at the sites. Computation of streamflow was not completed for this report. In addition to USGS streamgages, there are four sites with StormWatch gages (fig. 1; Overland Park, 2017) and previously established discharge ratings provided by the City of Overland Park (Dan Hurley, City of Overland Park, Kansas, written commun., 2015). These sites are Clear Creek at Woodland Road in Shawnee (site 14), Turkey Creek at Antioch [Street] in Overland Park (site 18), Coffee Creek at Pflumm Road in Johnson County (site 24), and Wolf Creek at 179th Street in Overland Park (site 26). StormWatch is a countywide flood warning system operated and maintained by the City of Overland Park. StormWatch streamgages transmit data twice daily, unless there is a minimum of 0.2 -foot change in stage, at which point transmission frequency increases to transmit with every 0.2 -foot change. Existing discharge ratings at these sites that are available from some municipalities are being evaluated to determine whether they are still valid in accordance with Bailey and Ray (1967) and may be used to determine streamflow for samples collected at these sites. For all other sites, indirect ratings have not been developed for this report; the next phase of the project includes developing indirect ratings or determining other methods to determine streamflow.

\section{Quality Assurance and Quality Control}

Quality assurance and quality control measures consistent with USGS policies and USGS Kansas Water Science Center quality assurance plans were followed (U.S. Geological Survey, 2006; Rasmussen and others, 2014). The Johnson County Environmental Laboratory, which provided the primary analyses, has analyzed water-quality samples as part of USGS cooperative projects since 2002 and has participated in the 
USGS standard reference sample program (U.S. Geological Survey, undated) for quality assurance every year since 2002 . The Johnson County Environmental Laboratory is accredited by The NELAC Institute (2016) and has produced consistent results of known quality for previous studies.

Quality control samples, including replicates and blanks, were collected and analyzed to identify and document possible sample contamination or bias and variability in sampling methods. A minimum of 10 percent of the total number of environmental samples were collected as replicate samples. Concurrent and sequential replicate samples also were used in this study to compare sampling methods (table 3 ). From January 2015 through June 2016, a total of 28 replicate pairs were analyzed for nutrients, 27 replicate sample pairs were analyzed for total suspended solids, 24 replicate pairs were analyzed for suspended-sediment concentration, and 23 replicate pairs were analyzed for $E$. coli bacteria. The relative percent difference, which was calculated by dividing the difference between replicate pairs by the mean of the two values and multiplying that value by 100 , was used to evaluate differences between replicate samples. One-half the detection limit was used to compute the relative percent difference for the small number (less than 1 percent) of replicate pair differences that included nondetection levels. The median relative percent difference for replicate samples was less than 10 percent, except for suspended-sediment concentration, which was 13.4 percent. The single largest relative percent difference among replicate samples was 76.5 percent for total suspended solids. Relative percent differences were within acceptable limits for all constituents, particularly considering this dataset includes some replicate samples collected using different field methods that were expected to produce more variable results.

\section{Results From Preliminary Assessment}

Because data collection has only been completed for 2 of the 5 years planned, discussion of specific data results is limited to a general discussion of total nitrogen, total phosphorus, E. coli bacteria, and total suspended solids for the purpose of illustrating general utility of the data for identifying pollutant sources and documenting effectiveness of and trends and improvements in management practices. Base flow and stormwater runoff data are provided in King and others (2017), which lists data for all samples collected, including some samples that did not meet minimum rainfall criteria described in stormwater permits.

\section{Base Flow Sample Data}

Base flow samples were collected from all sites in March 2015 and 2016 to compare with samples collected during storm runoff and identify sites where point sources may also be contributing to pollutant concentrations during storm runoff. Base flow data from site 1 on Kill Creek and sites 9 and 10 on Mill Creek had total nitrogen concentrations greater than 3 milligrams per liter $(\mathrm{mg} / \mathrm{L})$ in at least one of the two base flow samples (fig. 3) and total phosphorus concentrations greater than $1 \mathrm{mg} / \mathrm{L}$ in at least one of the two base flow samples (fig. 4), indicating that point sources are likely affecting nutrient concentrations. Wastewater treatment facilities are located upstream from these sites and are the most likely point sources affecting nutrients (Lee and others, 2005). Total nitrogen concentration in base flow samples from the upstream Mill Creek sites (site 9, Mill Creek near 114th Street, and site 10, Mill Creek at 85th Street) was greater in several storm samples (fig. 3) from the same sites and most storm samples from other sites. In addition, total nitrogen during base flow in 2016 at the upstream Kill Creek site (site 1, Kill Creek at 151st Street) had the second-highest concentration of all samples collected. Base flow total nitrogen concentrations at site 2 (Kill Creek at 95th Street), located downstream from site 1, and at site 15 (Mill Creek at Johnson Drive), located downstream from sites 9 and 10, were slightly higher than most other sites in Johnson County and are the only other sites located downstream from municipal wastewater treatment discharge.

Base flow total phosphorus concentrations also were larger than several storm runoff concentrations at the same

Table 3. Relative percentage difference summary for replicate sample pairs.

\begin{tabular}{|c|c|c|c|c|c|}
\hline \multirow{2}{*}{ Constituent } & \multicolumn{5}{|c|}{ Relative percentage difference } \\
\hline & Count & Minimum & Maximum & Mean & Median \\
\hline Phosphorus, water, unfiltered, milligrams per liter as phosphorus & 28 & 0.0 & 47.4 & 10.2 & 6.2 \\
\hline Nitrate plus nitrite, water, filtered, milligrams per liter as nitrogen & 28 & 0.0 & 69.2 & 6.4 & 3.7 \\
\hline Ammonia plus organic nitrogen, water, unfiltered, milligrams per liter as nitrogen & 28 & 0.0 & 41.2 & 8.9 & 5.3 \\
\hline Suspended-sediment concentration, milligrams per liter & 24 & 1.2 & 45.5 & 15.9 & 13.4 \\
\hline $\begin{array}{l}\text { Escherichia coli, defined substrate test method, water, most probable number per } \\
100 \text { milliliters }\end{array}$ & 23 & 0.0 & 48.8 & 14.0 & 9.7 \\
\hline
\end{tabular}




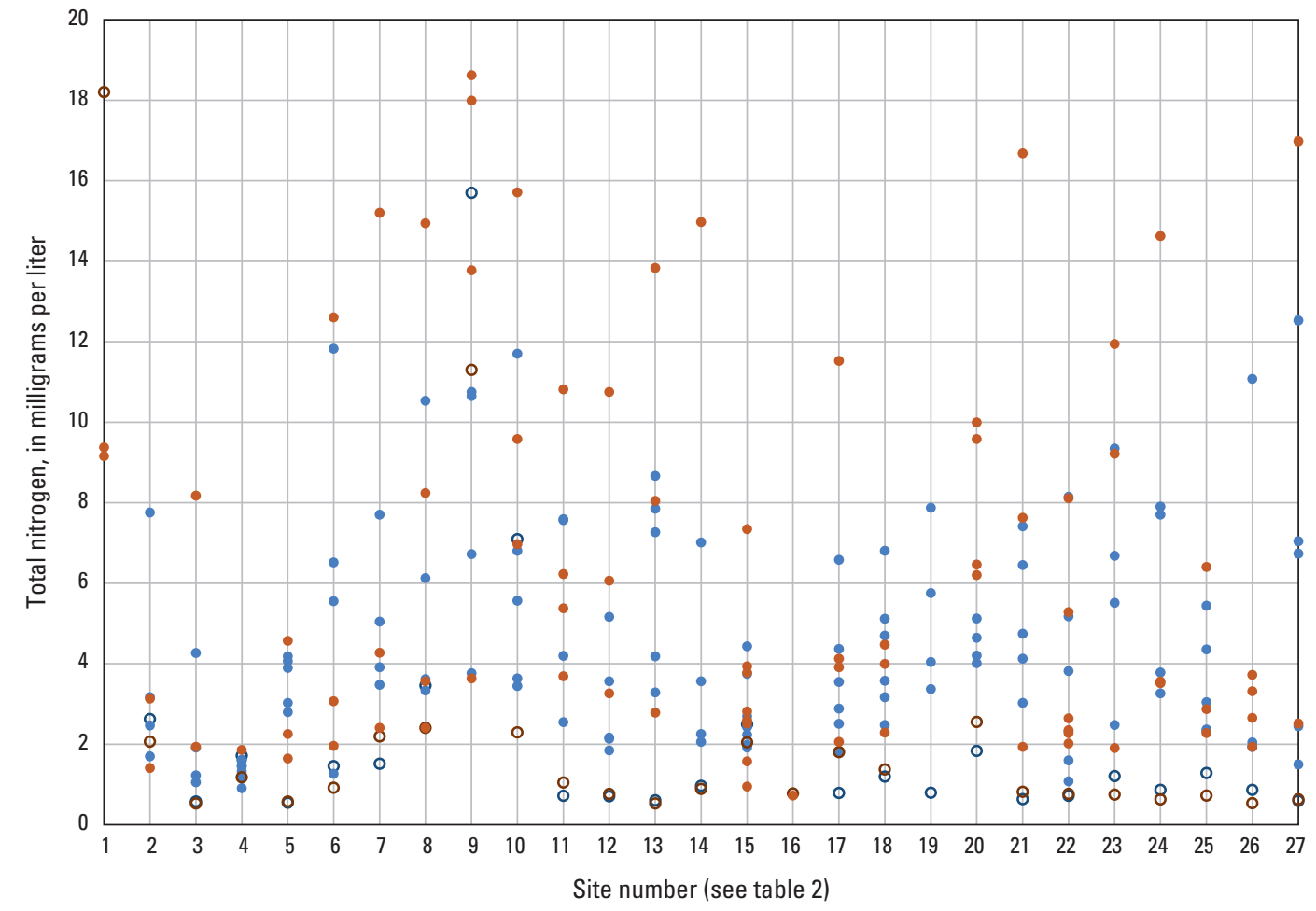

EXPLANATION

- 2015 base flow

- 2015 storm runoff

- 2016 base flow

- 2016 storm runoff

Figure 3. Total nitrogen concentrations in base flow and storm runoff samples from 27 sites in Johnson County, Kansas, from January 2015 to June 2016. Site numbers are listed in table 2.

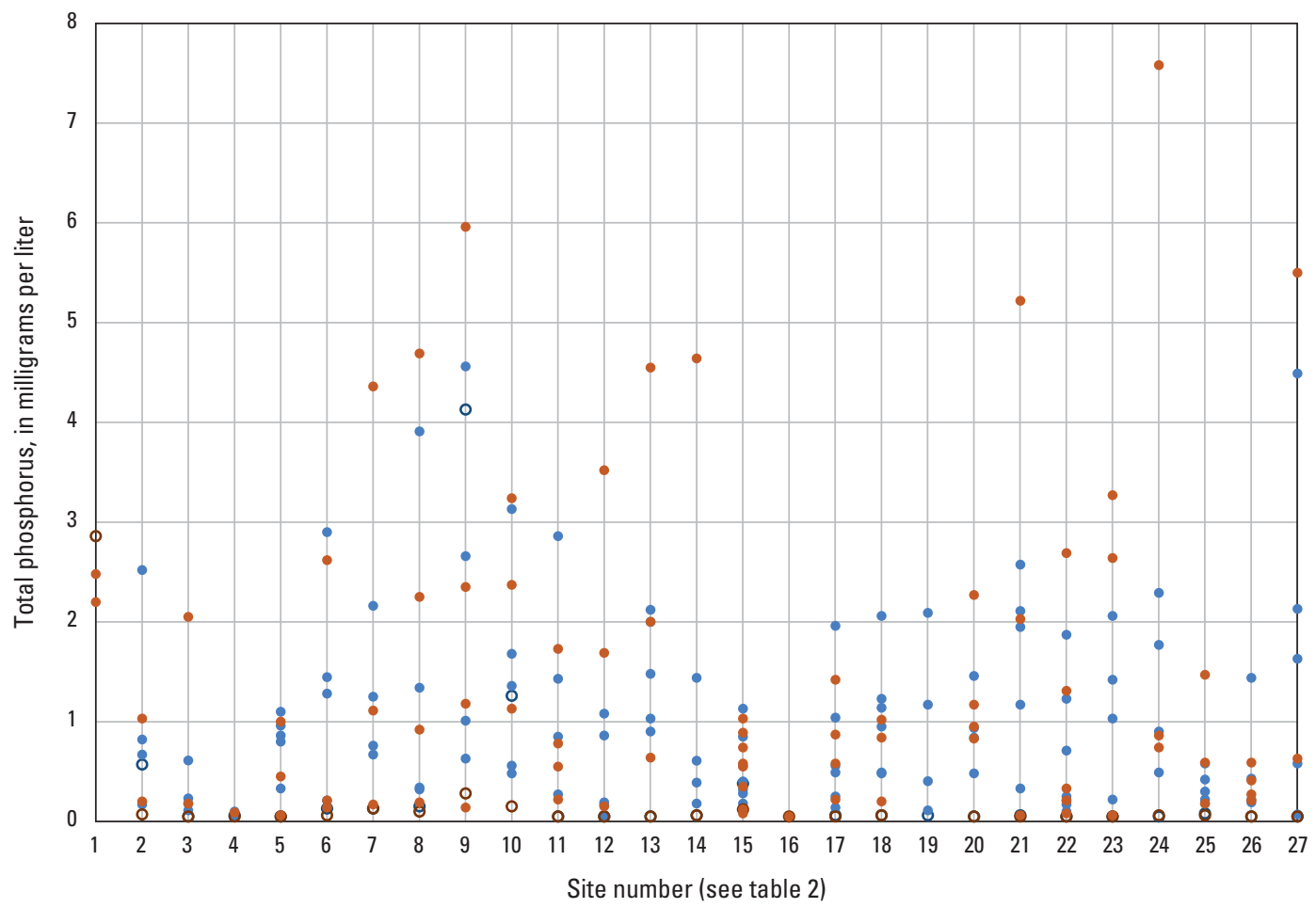

EXPLANATION

- 2015 base flow

- 2015 storm runoff

- 2016 base flow

- 2016 storm runoff

Figure 4. Total phosphorus concentrations in base flow and storm runoff samples from 27 sites in Johnson County, Kansas, from January 2015 to June 2016. 
three sites (fig. 4). Similar patterns were found in base flow samples from 2002-03 (Lee and others, 2005) except that upstream concentrations of both nitrogen and phosphorus were greater in 2015-16 than in 2002-03. Sites 12 (Little Mill Creek at 79th Street), 17 (Turkey Creek near 75th Street), and 18 (Turkey Creek at Antioch) had base flow E. coli densities greater than 1,000 colonies per 100 milliliters $(\mathrm{col} / 100 \mathrm{~mL}$; fig. 5), indicating sources of indicator bacteria other than stormwater runoff. No sites had elevated total suspended solids during base flow (fig. 6).

These examples illustrate the value of the base flow data for distinguishing some point source pollutants from pollutants carried by storm runoff and determining relative contributions from each. However, one base flow sample annually is a limited dataset; data interpretation could become more meaningful with additional samples to identify patterns and outliers.

\section{Stormwater Sample Data}

Nutrient concentrations in all stormwater runoff samples collected from January 2015 through June 2016 were characterized by substantial variability among sites and samples (figs. 3 and 4). The highest total nitrogen concentrations in stormwater runoff (about $18 \mathrm{mg} / \mathrm{L}$ ) occurred at site 9 (Mill Creek near 114th Street; fig. 3). About one-half of the sites, representing different watersheds, had stormwater samples with nitrogen concentrations greater than $10 \mathrm{mg} / \mathrm{L}$ (fig. 3). The highest total phosphorus concentration (about $7.6 \mathrm{mg} / \mathrm{L}$ ) was from site 24 (Coffee Creek at Pflumm Road; fig. 4). About one-third of the sites, representing different watersheds, had total phosphorus concentrations greater than $3 \mathrm{mg} / \mathrm{L}$ (fig. 4). E. coli densities in stormwater runoff samples typically ranged from about 1,000 to $100,000 \mathrm{col} / 100 \mathrm{~mL}$ at most sites (fig. 5). Sites 9, 12, 17, 18, 20, and 24, representing Coffee, Mill, Turkey, and Tomahawk Creeks, had E. coli densities greater than $100,000 \mathrm{col} / 100 \mathrm{~mL}$ (fig. 5). The highest total suspended solids concentrations of about $12,000 \mathrm{mg} / \mathrm{L}$ or more occurred in Clear Creek (site 11), Coffee Creek (site 24), and Tomahawk Creek (site 21). As more data are collected, statistical tools such as interquartile ranges (Helsel and Hirsch, 2002) may be useful for evaluating patterns in stormwater runoff samples, identifying samples and sites of concern, and establishing pollutant reduction goals. In addition, comparisons of concomitant streamflows for all samples would be more meaningful.

\section{Continuous Water-Quality Data}

Continuous measurements of nitrate plus nitrite indicated fluctuations from 0.1 to $9.7 \mathrm{mg} / \mathrm{L}$, a mean value of $1.5 \mathrm{mg} / \mathrm{L}$, and median value of $1.3 \mathrm{mg} / \mathrm{L}$ from January 2015 through June 2016 (fig. 7; table 4). The range in concentrations from 18 discrete samples was 0.24 to $6.24 \mathrm{mg} / \mathrm{L}$, with a mean value

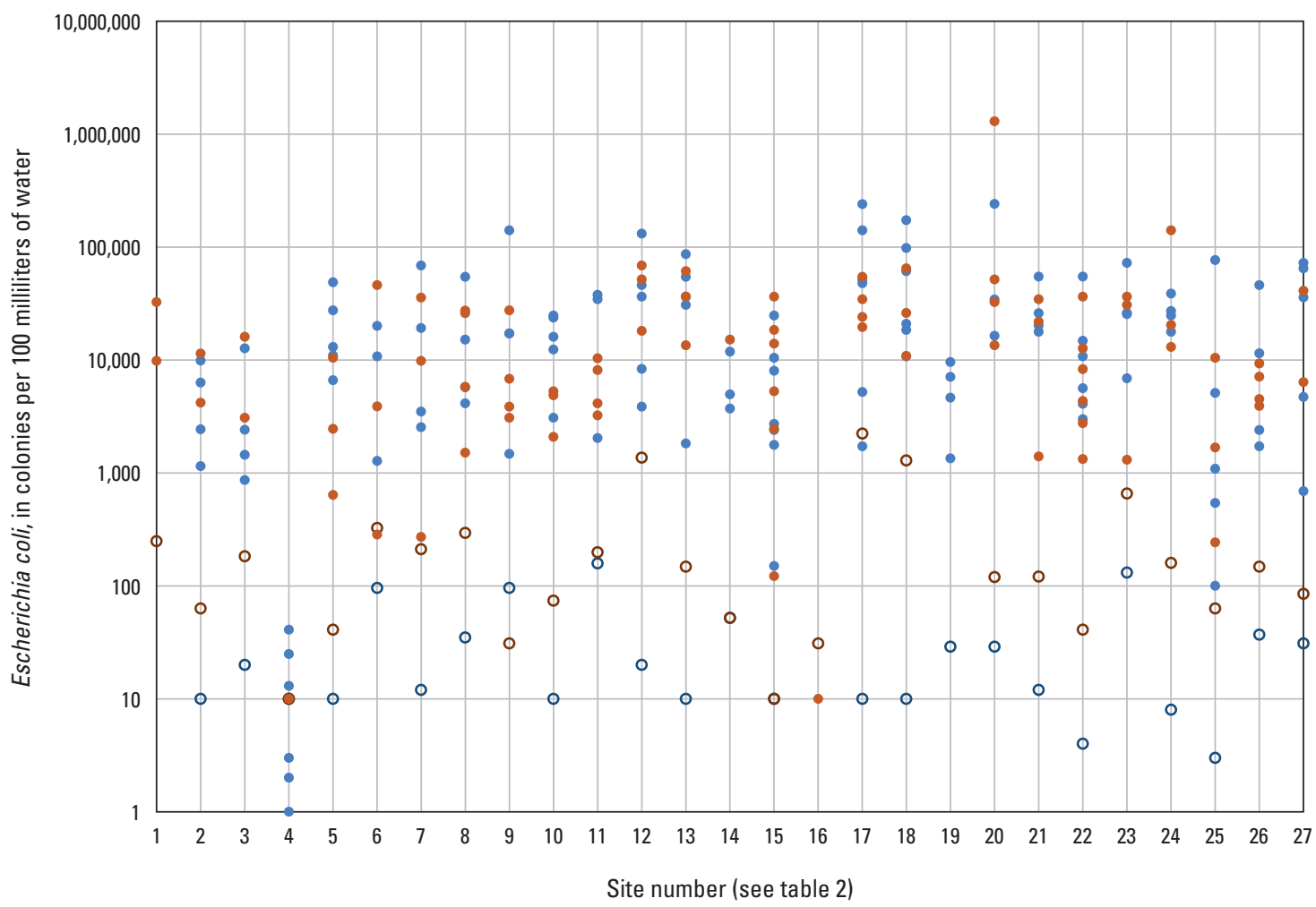

EXPLANATION

- 2015 base flow

- 2015 storm runoff

- 2016 base flow

- 2016 storm runoff

Figure 5. Escherichia coli densities in base flow and storm runoff samples from 27 sites in Johnson County, Kansas, from January 2015 to June 2016. 


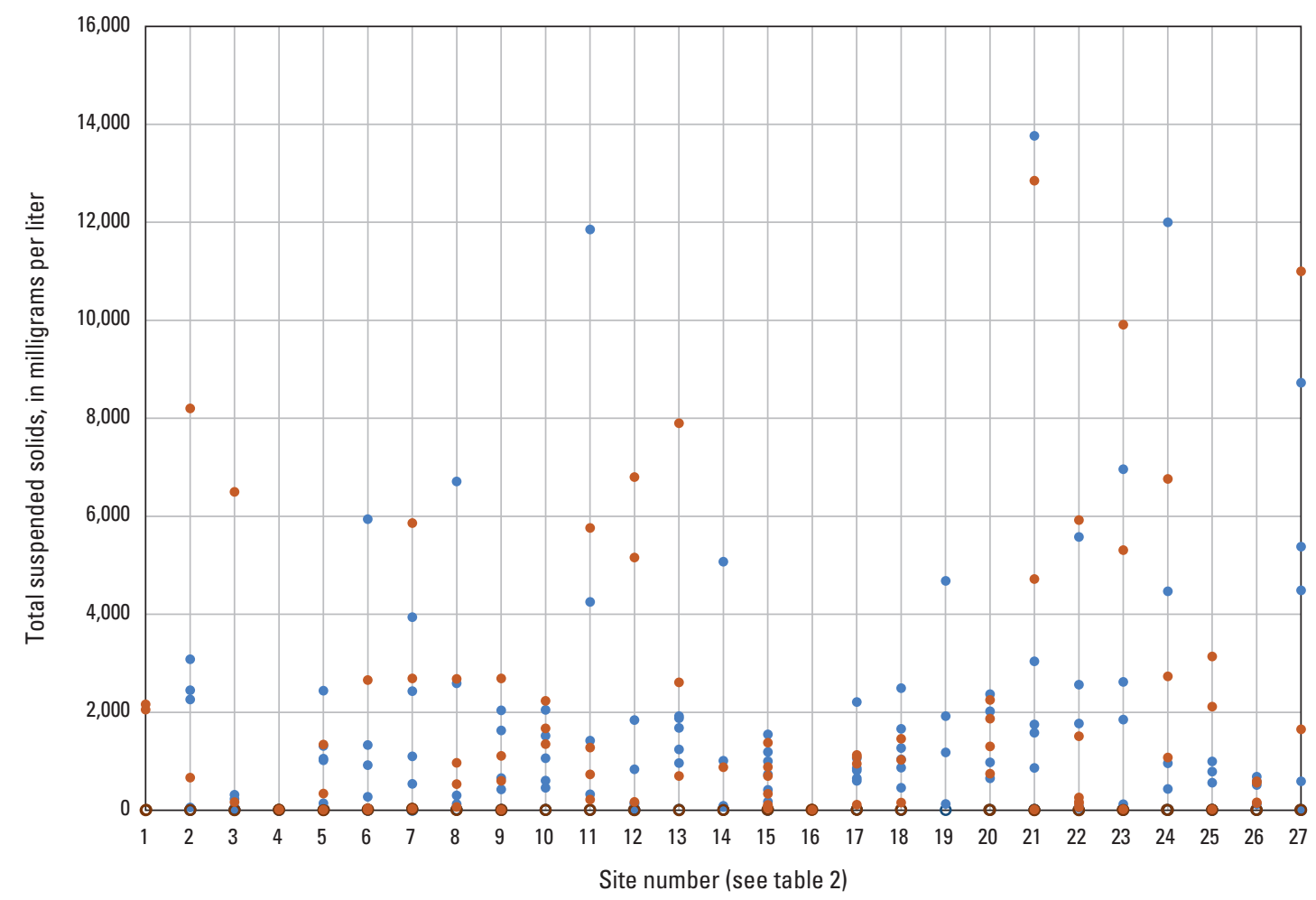

EXPLANATION

- 2015 base flow

- 2015 storm runoff

- 2016 base flow

- 2016 storm runoff

Figure 6. Total suspended solids concentrations in base flow and storm runoff samples from 27 sites in Johnson County, Kansas, from January 2015 to June 2016.

of $1.24 \mathrm{mg} / \mathrm{L}$ and a median value of $0.89 \mathrm{mg} / \mathrm{L}$, calculated from data in U.S. Geological Survey (2016a,b), excluding replicates (the dataset used for the analysis is replicated in King and others, 2017). In June 2016, nitrate plus nitrite ranged from 0.55 to $9.5 \mathrm{mg} / \mathrm{L}$ in a less-than-24-hour period, demonstrating rapid change that is difficult to document using discrete sampling approaches. The range in concentrations for discrete samples in 2015 (0.43 to $1.89 \mathrm{mg} / \mathrm{L}$; U.S. Geological Survey, 2016a,b) was much smaller than the range in continuous data ( 0.2 to $6.6 \mathrm{mg} / \mathrm{L}$ ) during the same period. Annual nitrate plus nitrite load for 2015 calculated from discrete samples was 89 (short) tons, which is nearly the same as the annual load of 87 (short) tons calculated using continuous data. Surrogate models to be developed after additional data are collected are expected to help document variability for additional nutrient constituents, total suspended solids, suspended sediment, and E. coli bacteria.

\section{Evaluation of Data Utility}

Based on a preliminary assessment of data collection to date and from previous USGS studies, the sample data being collected for the 5-year monitoring program as currently designed are useful for some general assessment purposes but are limited in potential to fully inform stormwater management activities. The complexities of urban pollutant sources and altered hydrology make characterization of urban water quality especially challenging. Understanding the utility of the data being collected as part of this monitoring program is important for understanding how the data will be used, limitations of the data collection approach, reasonable expectations for decision making, and potential for making improvements in future monitoring efforts. Table 5 summarizes valuable and limiting attributes of the initial design phase of the monitoring program and possible approaches for making improvements.

The primary objective of the initial phase of the monitoring program is to meet monitoring requirements as described by municipal stormwater permits, primarily, collection of four storm runoff samples annually during the rising limb of qualifying rainfalls. Several attributes of the monitoring program are valuable for achieving this objective and have additional benefits (table 5). By locating monitoring sites at or near jurisdictional boundaries, data were collected from many sites representing different watersheds throughout the county. This approach provides a countywide perspective of water quality, helps identify sites with recurring elevated concentrations, and allows for some general speculation about sources. Data from multiple watersheds allow for comparisons across watersheds and facilitate a consistent monitoring approach among municipalities without unnecessary duplication of effort. Fixed-stage samplers facilitate collection of storm samples from many sites across the county during the same runoffs (many of 


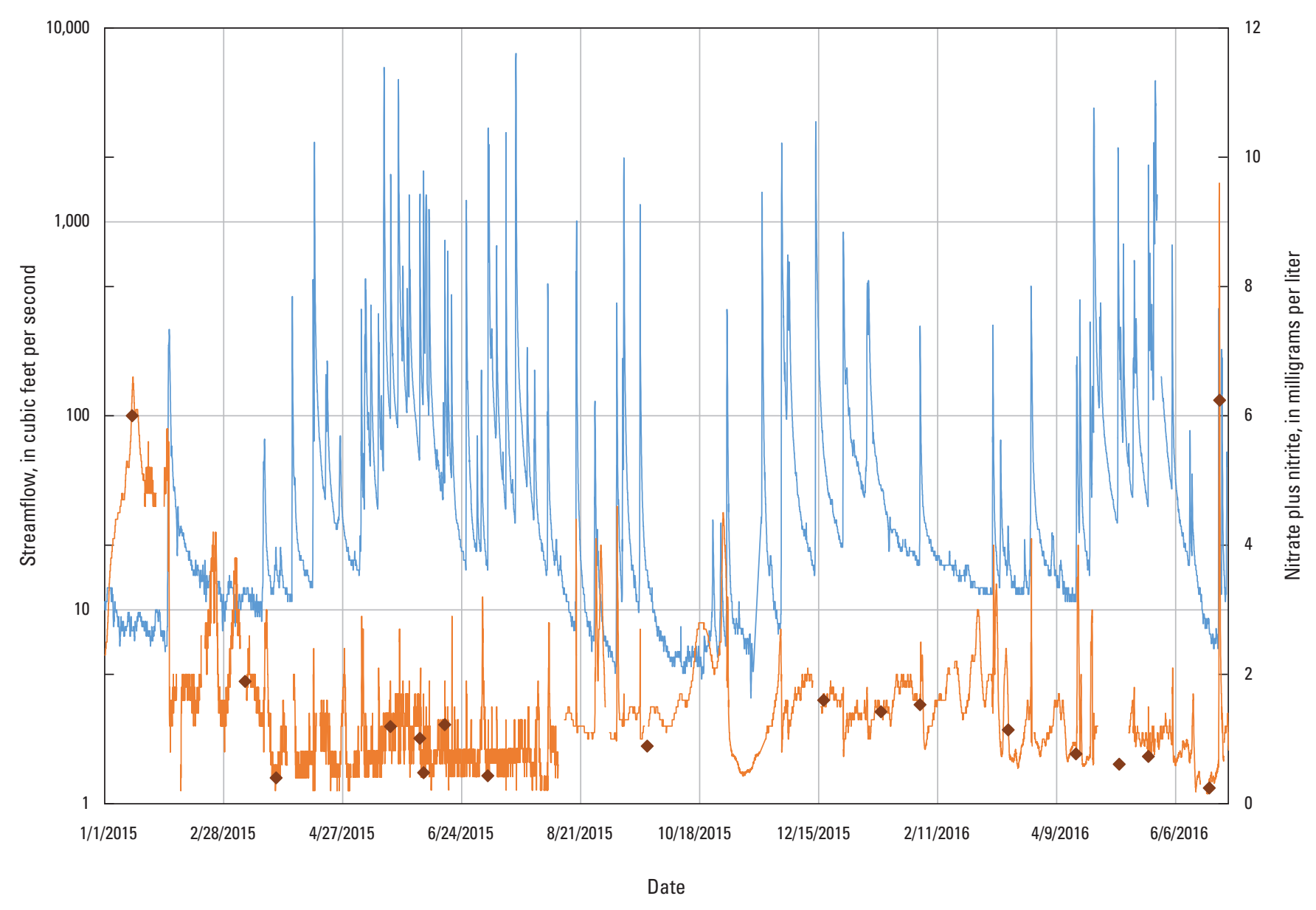

EXPLANATION

Streamflow, in cubic feet per second

Nitrate plus nitrite, in milligrams per liter

- Nitrate plus nitrite sample, in milligrams per liter

Figure 7. Continuous and discrete nitrate plus nitrite data from the monitoring site on Mill Creek at Johnson Drive, Shawnee, in Johnson County, Kansas, from January 2015 to June 2016. Continuous nitrate plus nitrite data were collected through the use of a Hach Co. Nitratax nitrate sensor.

which occurred during the night when other sampling methods are problematic) and allow comparisons during comparable streamflow conditions. Two data collection components were included in the monitoring program that were not required by permits. Base flow samples help to distinguish sites with point sources that may also be contributing pollutants to storm runoff. Regression models using continuous water-quality data characterize variability in concentrations, loads, and hydrology. The value of this approach has been demonstrated in previous studies of Johnson County streams. For example, Rasmussen and others (2008) used continuous, computed suspended-sediment concentrations to show that at least 90 percent of the total annual sediment load during 2005-06 in five primary watersheds occurred in less than 2 percent of the time, generally during periods of high stormwater runoff.
Although the existing monitoring program generally meets permit requirements, there are several limitations to the design (table 5).

- Stormwater discharge permits require municipalities to control pollutant sources and install BMPs and to monitor the effectiveness of those efforts in achieving goals for pollution reduction (Kansas Department of Health and Environment, 2016b). Locating sampling sites along jurisdictional boundaries instead of using watershed criteria resulted in several sites that were not suitable or of strategic value for identifying sources or evaluating BMPs. For example, sites 1 and 2 on Kill Creek are located on the municipal boundaries of Gardner, unincorporated Johnson County, and DeSoto, but no sites are located on the larger tributaries of 
Table 4. Summary of continuous water-quality data from Mill Creek at Johnson Drive, Shawnee, Johnson County, Kansas, January 2015-June 2016.

\begin{tabular}{lcccc}
\hline \multicolumn{1}{c}{ Water-quality parameter } & Maximum & Minimum & Mean & Median \\
\hline Streamflow, cubic feet per second & 7,390 & 4 & 85 & 20 \\
Specific conductance, microsiemens per centimeter & 2,550 & 178 & 930 & 880 \\
Water temperature, degrees Celsius & 32.7 & 0.0 & 14.5 & 15.1 \\
pH, standard units & 9.0 & 7.2 & 8.1 & 8.1 \\
Dissolved oxygen, milligrams per liter & 21.5 & 3.8 & 10.8 & 9.9 \\
Turbidity, formazin nephelometric units & 1,310 & 1 & 22 & 7 \\
Nitrate plus nitrite, milligrams per liter & 9.7 & 0.1 & 1.5 & 1.3 \\
\hline
\end{tabular}

Spoon Creek or the Kill Creek East Fork, which may be contributing nutrients, E. coli bacteria, and sediment to Kill Creek. Sites 23 and 24, also on municipal boundaries, are close together and sample results may be redundant. Another example is in the Mill Creek watershed, where seven monitoring sites are located along jurisdictional boundaries but none are placed in close proximity to known BMPs. Sites 11 and 12 in the Mill Creek watershed and site 20 in the Tomahawk Creek watershed may be too far upstream and not needed.

- Having a large number of widespread sampling locations presents logistical challenges for predicting localized rainfall, collecting samples, and analyzing samples during short timeframes associated with storm events.

- Collection of all or the majority of storm samples with water samplers at fixed-stage elevations only during the rising limb of storm events does not characterize conditions over the storm hydrograph. Previous water-quality studies in Johnson County have shown that peaks in pollutant concentrations are not always coincident with streamflow and can occur prior to or following streamflow peaks (Lee and others, 2008; Rasmussen and Gatotho, 2014).

- The small sample size per site is a limitation. Previous studies in Johnson County (for example, Rasmussen and Gatotho, 2014) show that collection of only four samples per site annually, the minimum number required by stormwater permits, results in a sample size too small to be representative of site conditions and does not encompass seasonal and hydrologic variability. In addition, the number of samples is too small to detect changes over time (U.S. Department of Agriculture, 2003) or to allow correlating changes with implemented BMPs (Betanzo and others, 2015).

Sampling frequency and duration is affected by study objectives, statistical confidence needed to achieve those objectives, data variability, and the complexity of the aquatic system being studied (U.S. Department of Agriculture, 2003). For example, using a random sampling design, an estimated 70 samples are needed to estimate the mean for a stream's water quality constituent within 20 percent of the true mean. Daily or weekly sampling is usually necessary to document effectiveness of a single BMP (Dressing and others, 2016). A case study evaluating monitoring design for determining effectiveness of management practices in reducing nutrient tributary loads to Lake Erie found that total phosphorus in a watershed must be reduced by 40 percent for a monthly sampling program to detect change with statistical significance within 10 years (Betanzo and others, 2015).

Several measures could be taken to improve data utility (table 5). To be successful, in addition to meeting permit monitoring requirements, effective municipal stormwater monitoring programs establish objectives for providing reliable information to identify pollutant sources; characterizing occurrence of pollutants and factors affecting sources of water; documenting compliance with water-quality standards; informing municipal engineers of design, selection, and location of source controls and BMPs; monitoring changes over time; and assessing factors such as BMPs affecting those changes. Redesigning the monitoring network based on watershed characteristics such as tributary locations, land use, and BMP placement (Dressing and others, 2016) rather than jurisdictional boundaries could increase efficiency by increasing the likelihood of identifying and characterizing sources and BMP effectiveness. A commitment to long-term monitoring at some sites within the network is important because it allows trend analysis, incorporates hydrologic variability, and allows time (sometimes as much as years) for water quality to respond to implemented BMPs (U.S. Department of Agriculture, 2003). Another necessity for evaluating BMPs is maintaining complete and long-term documentation of BMP activity that can be tied to water quality. In addition, collecting samples at a higher frequency will better characterize variability and enable more meaningful comparisons among sites, results of statistical tests with higher confidence levels, more accurate estimation of loads, and improved documentation of changes over time. 
Table 5. Summary of valuable and limiting attributes of the current water-quality monitoring program in Johnson County, Kansas, and possible approaches for making improvements.

[BMP, best management practice]

\begin{tabular}{lc}
\hline \multicolumn{1}{c}{ Attribute } & Explanation \\
\hline Storm samples from many sites located across the county & Valuable attributes \\
& $\begin{array}{c}\text { Data from multiple watersheds provide countywide perspective and al- } \\
\text { lows comparison across the county. } \\
\text { Identifies sites with recurring elevated concentrations. } \\
\text { Data from multiple sites within watershed allows some speculation } \\
\text { about sources. } \\
\text { Consistent approach without unnecessary duplication of effort among } \\
\text { municipalities. }\end{array}$ \\
Fixed-stage samplers & $\begin{array}{c}\text { Facilitates sampling at multiple sites during single event and allows data } \\
\text { comparison during comparable streamflow conditions. }\end{array}$ \\
Base-flow samples & $\begin{array}{c}\text { Identifies sites with point pollutant sources as distinguished from } \\
\text { stormwater (nonpoint) sources. }\end{array}$ \\
Continuous water-quality data and models & $\begin{array}{c}\text { Best method for characterizing variability in concentrations, loads, and } \\
\text { hydrology. }\end{array}$ \\
\hline
\end{tabular}

Limiting attributes

Monitoring sites located along jurisdictional boundaries $\quad$ Some locations are not suitable or of strategic value for addressing questions on sources and BMP effectiveness.

Storm samples from many sites located across the county

Presents logistical challenges for collection and analysis of large number of samples in short time frames associated with storm events.

Fixed-stage samplers

Four storm samples annually
Does not characterize conditions over storm hydrograph.

Number of samples is too small to be representative of site conditions; does not describe seasonal and hydrologic variability.

Sample set too small to detect changes over time.

Not likely to identify or characterize non-point sources.

Not likely to demonstrate BMP effectiveness.

Possible improvement approaches

Redesign sampling network based on watersheds rather than jurisdictional boundaries

Locate sites to correspond with incoming tributaries, conditions, land use, and BMPs of interest.

Incorporate nested designs (watershed, sub-watershed, and BMP scales) and adjust sampling frequency depending on type of site

Collect a larger number of samples at fewer sites

Monitoring at different scales can better characterize sources. Dynamic and flexible sampling allows for focus on conditions of interest.

Larger sample size enables more accurate characterization of water quality and trends.

Fewer sites allows for better watershed-wide sampling response and reduces logistical challenges of anticipating localized rainfall and collecting large number of samples from widespread sites.

Install continuous water-quality monitors at more sites

Best method for characterizing variability in concentrations, loads, and hydrology.

Incorporate different sampling methods such as nested, Lagrangian, ${ }^{*}$ high-frequency, and source-targeted approaches into sampling design

Consider alternatives to using qualifying storms for determining suitable storm-sampling conditions
Variety in data collection methods allows for focus on conditions of particular interest.

Streamflow response may be more suitable under some circumstances for identifying storm-sampling conditions.

*Sampling the same parcel of water as it moves downstream. 
A variety of different data collection methods could be incorporated into the monitoring design. A nested design, in which data are collected at different scales (watershed, subwatershed, and BMP) and different frequencies, allows for flexibility to focus on areas and conditions of particular interest or concern. Collecting more samples per site enables more accurate characterization of water quality and trends at specific sites. Lagrangian approaches, in which a parcel of water is sampled as it moves downstream (Moody, 1993), could be used to locate and evaluate nutrient or E. coli sources. Sourcetargeted approaches allow focus on select conditions and constituents of interest. Periods of high temporal or spatial frequency data collection help describe important factors contributing toward stream impairments such as sources and runoff events. Incorporating more continuous water-quality monitors enables collection of high-frequency data to better characterize variability in concentrations, loads, and hydrology. The 0.5 -inch precipitation criterion for qualifying storms is not always the best indicator of adequate runoff for collecting storm samples. Depending on antecedent moisture and rainfall intensity, 0.5 inches of rain can result in small amounts of runoff and minimal changes in streamflow. Conversely, less than 0.5 inches of rainfall can result in substantial runoff and increases in streamflow. Therefore, streamflow response may be more useful for identifying suitable storm sampling conditions at sites where there are no artificial upstream discharges. Potential monitoring designs that incorporate all or most of these suggested improvements could enable focusing resources on a limited number of watersheds for a 2- to 3-year period, then cycling to the next set of watersheds for 2 to 3 years, eventually returning to previously monitored watersheds to document changes.

Redesign of the water-quality monitoring program may require considerable effort and commitment from the municipalities of Johnson County. However, the long-term benefit is likely to be a monitoring program that could result in more effective management practices and efficient expenditure of resources. Improvements would require an increase in the amount of data collected and revisions to monitoring requirements in stormwater permits to ensure monitoring design meets permit requirements. A unique opportunity exists to make these changes because an effort is underway by the county and municipalities to establish a new watershedbased management structure that allows for comprehensive water-quality improvement plans (Black and Veatch Holding Company, 2016).

\section{Summary and Conclusions}

Municipalities in Johnson County in northeastern Kansas are required to implement stormwater management programs to reduce pollutant discharges, protect water quality, and satisfy applicable water-quality regulations in accordance with National Pollutant Discharge Elimination System (NPDES) permits for stormwater discharge. In 2014, a 5-year monitoring program was initiated by the U.S. Geological Survey (USGS) in cooperation with the Johnson County Stormwater Management Program to meet new stormwater monitoring requirements from the Kansas Department of Health and Environment (KDHE) and to evaluate the utility of different types of data in assessing improvements in water quality. The purpose of this report is to provide a preliminary assessment of the monitoring program. The monitoring program is described, a preliminary assessment of the monitoring program design is provided using water-quality data collected during the first 2 years of the program, and the ability of the current monitoring network and sampling plan to provide data sufficient to quantify improvements in water quality resulting from implemented and planned best management practices (BMPs) is evaluated.

Water-quality monitoring requirements and improvement goals are based upon the TMDLs primarily for nutrients, sediment, and fecal bacteria. Twenty municipalities in Johnson County share all or parts of 22 watersheds making a cooperative effort among municipalities the most practical approach to meeting NPDES compliance requirements. At a minimum, municipalities are required by the KDHE to collect grab samples during the rising stages of four runoffs annually at stream locations entering and leaving their jurisdictional areas. The ability to characterize stormwater quality and effectiveness of BMPs on the basis of such a limited dataset is questionable because the dataset likely is not representative of site variability and conditions and is insufficient for meaningful statistical analysis, and the approach could result in misleading data interpretations by stakeholders and poor information for decision-making related to TMDLs and BMP effectiveness.

Data collected in 2015-16 were used to evaluate changes in the design of the monitoring program that would lead to improved data utility while data collection is still ongoing. Discrete water-quality samples were collected at 27 sites and analyzed for nutrients, Escherichia coli (E. coli) bacteria, total suspended solids, and suspended-sediment concentrations. A continuous water-quality monitor was operated at one site and measured water temperature, $\mathrm{pH}$, dissolved oxygen, specific conductance, and turbidity. A second monitor at the same site provided continuous measurements of nitrate plus nitrite.

A monitoring network of 25 stream sites and 2 lake sites was established. Sites were selected to bracket municipal boundaries and use previously established sampling sites for historical context. Emphasis for site selection was placed on municipal boundaries because municipalities are required by their permits to monitor water quality as dictated by the KDHE-designated TMDLs. Discrete samples were collected for analysis of nutrients (dissolved phosphorus, total phosphorus, orthophosphate, nitrate plus nitrite, nitrite, ammonia, and ammonia plus organic nitrogen), E. coli bacteria, total suspended solids, and suspended sediment. In addition, chlorophyll $\alpha$ and pheophytin $\alpha$ samples were collected from the lake sites. A continuous, real-time water-quality monitor and a nitrate monitor were deployed at one site to evaluate 
water-quality variability and pollutant loading. Continuous, real-time monitors provide the best available water-quality information during storm runoff when conditions are changing rapidly. Surrogate models that define relations between in-place monitoring data and laboratory-analyzed data make it possible to provide continuous real-time computations for particular constituents of concern.

Because data collection is incomplete, data results are limited to total nitrogen, total phosphorus, E. coli bacteria, and total suspended solids for the purpose of evaluating general utility of the data to identify pollutant sources and document improvements, trends, and effectiveness of BMPs. Base flow data from three sites had total nitrogen concentrations greater than 3 milligrams per liter $(\mathrm{mg} / \mathrm{L})$ in at least one of the two base flow samples and total phosphorus concentrations greater than $1 \mathrm{mg} / \mathrm{L}$ in at least one of the two base flow samples, indicating that point sources are likely affecting nutrient concentrations. Three sites had base flow E. coli densities greater than 1,000 colonies per 100 milliliters ( $\mathrm{col} / 100 \mathrm{~mL}$ ), indicating sources other than stormwater runoff for bacteria. No sites had elevated total suspended solids during base flow.

Nutrient concentrations in all storm runoff samples collected from January 2015 through June 2016 were characterized by substantial variability among sites and samples. About one-half of the sites, representing different watersheds, had stormwater samples with nitrogen concentrations greater than $10 \mathrm{mg} / \mathrm{L}$. About one-third of the sites, representing different watersheds, had total phosphorus concentrations greater than $3 \mathrm{mg} / \mathrm{L}$. Six sites representing Coffee, Mill, Turkey, and Tomahawk Creeks had E. coli densities greater than $100,000 \mathrm{col} / 100 \mathrm{~mL}$. The largest total suspended solids concentrations of about $12,000 \mathrm{mg} / \mathrm{L}$ or greater occurred in Clear, Coffee, and Tomahawk Creeks.

Based on a preliminary assessment of data collection to date and from previous USGS studies, the sample data being collected for the initial design phase of the 5-year monitoring program are useful for some general assessment purposes but are limited in potential to fully inform stormwater management activities. Understanding the utility of the data being collected as part of this monitoring program is important for understanding how the data will be used, limitations of the data collection approach, reasonable expectations for decisionmaking, and options for making improvements in future monitoring efforts.

Several attributes of the monitoring program are valuable for achieving the objective of meeting monitoring requirements as described by stormwater permits and have additional benefits. By locating monitoring sites at or near jurisdictional boundaries, data were collected from many sites representing different watersheds throughout the county providing a countywide perspective of water quality. Data from multiple watersheds allow for comparisons across watersheds and facilitate a consistent monitoring approach among municipalities without unnecessary duplication of effort. Fixed-stage samplers facilitate collection of storm samples from many sites across the county during the same runoffs. Base flow samples help to distinguish sites with point sources that may also be contributing during storm runoff. Regression models using continuous water-quality data characterize variability in concentrations, loads, and hydrology.

Although the existing monitoring program generally meets permit requirements, there are several limitations to the design. Locating sampling sites along jurisdictional boundaries instead of using watershed criteria resulted in several sites not suitable or of strategic value for identifying sources or evaluating BMPs. In addition, having a large number of widespread sampling locations presented logistical challenges for predicting localized rainfall, collecting samples, and analyzing samples during short timeframes associated with storm events. Collection of storm samples at fixed-stage elevations only during the rising limb of storm events did not characterize conditions over the storm hydrograph. Finally, and perhaps most importantly, the small sample size per site resulted in a dataset too small to be representative of site conditions, including seasonal and hydrologic variability, and insufficient for meaningful statistical analysis comparing sites and trends or for site-specific modeling.

Several measures could be taken to improve data utility. Redesigning the monitoring network based on watershed characteristics, such as tributary locations, land use, and BMP placement rather than jurisdictional boundaries, could increase efficiency by increasing the likelihood of identifying and characterizing sources and BMP effectiveness. Also, collecting samples at a higher frequency should help better characterize variability and enable more meaningful comparisons among sites, statistical tests with more confidence, more accurate estimation of loads, and improved documentation of changes over time. A variety of different data collection methods could be incorporated into the monitoring design. A nested design in which data are collected at different scales (watershed, subwatershed, and BMP) could allow for flexibility to focus on areas and conditions of particular interest or concern. Lagrangian approaches could be used to locate and evaluate nutrient or $E$. coli sources. Use of periods of high temporal or spatial frequency data collection could help describe important factors contributing toward stream impairments, such as sources and storm runoff. Collecting a larger number of samples (perhaps by reducing the number of sites if necessary) would enable more accurate characterization of water quality and trends. Incorporating more continuous water-quality monitoring sites would enable collection of high frequency data to better characterize variability in concentrations, loads, and hydrology. A monitoring design that would facilitate most of these improvements could be to focus efforts on a limited number of watersheds for several years, then cycle to the next set of watersheds for several years, eventually returning to previously monitored watersheds to document changes.

Redesign of the water-quality monitoring program may require considerable effort and commitment from municipalities of Johnson County. However, the long-term benefit likely is a monitoring program that results in more effective management practices and efficient expenditure of resources. 
Improvements would require an increase in the amount of data collected and revisions to monitoring requirements in stormwater permits to ensure monitoring design meets permit requirements. A unique opportunity exists to make these changes because an effort is underway by the county and municipalities to establish a new watershed-based management structure that allows for comprehensive water-quality improvement plans.

\section{References Cited}

American Public Health Association, American Water Works Association, and Water Environment Federation, 1995, Standard methods for the examination of water and wastewater (19th ed.): Washington, D.C., American Public Health Association, 905 p.

Arar, E.J., and Collins, G.B., 1997, In vitro determination of chlorophyll $a$ and pheophytin $a$ in marine and freshwater algae by fluorescence, revision 1.2: U.S. Environmental Protection Agency Method 445.0, 22 p. [Also available at https://cfpub.epa.gov/si/si_public_record_report. cfm?dirEntryId=309417.]

Bailey, J.F., and Ray, H.A., 1967, Definition of stage-discharge relations in natural channels by step-backwater analysis, chap. A of River hydraulics: U.S. Geological Survey Water-Supply Paper 1869, 24 p. [Also available at https://pubs.er.usgs.gov/publication/wsp1869A.]

Bennett, T.J., Graham, J.L., Foster, G.M., Stone, M.L., Juracek, K.E., Rasmussen, T.J., and Putnam, J.E., 2014, U.S. Geological Survey quality-assurance plan for continuous water-quality monitoring in Kansas, 2014: U.S. Geological Survey Open-File Report 2014-1151, 70 p., accessed October 2016 at https://doi.org/10.3133/ofr20141151.

Betanzo, E.A., Choquette, A.F., Reckhow, K.H., Hayes, L., Hagen, E.R., Argue, D.M., and Cangelosi, A.A., 2015, Water data to answer urgent water policy questionsMonitoring design, available data and filling data gaps for determining the effectiveness of agricultural management practices for reducing tributary nutrient loads to Lake Erie: Washington, D.C., Northeast-Midwest Institute nutrient case study report, $150 \mathrm{p}$. [Also available at http://www.nemw.org/wp-content/uploads/2016/06/ Final-Nutrient-Case-Study-Report.pdf.]

Black and Veatch Holding Company, 2016, 2016 strategic plan-Stormwater management program, Johnson County, Kansas: Olathe, Kans., Johnson County Public Works and Infrastructure, accessed October 2016 at https://www.jocogov.org/sites/default/files/documents/ PWK/JOCO \%20SMP\%20Strategic\%20Plan\%20Draft $\% 20$ Full\%20Report.pdf.
Coles, J.F., McMahon, Gerard, Bell, A.H., Brown, L.R., Fitzpatrick, F.A., Eikenberry, B.C.S., Woodside, M.D., Cuffney, T.F., Bryant, W.L., Cappiella, Karen, FraleyMcNeal, Lisa, and Stack, W.P., 2012, Effects of urban development on stream ecosystems in nine metropolitan study areas across the United States: U.S. Geological Survey Circular 1373, 138 p. [Also available at https://pubs.er.usgs.gov/publication/cir1373.]

Dressing, S.A., Meals, D.W., Harcum, J.B., Spooner, Jean, Stribling, J.B., Richards, R.P., Millard, C.J., Lanberg, S.A., and O'Donnell, J.G., 2016, Monitoring and evaluating nonpoint source watershed projects: U.S. Environmental Protection Agency EPA 841-R-16-010, [variously paged]. [Also available at https://www.epa.gov/sites/production/ files/2016-06/documents/nps_monitoring_guide_ may_2016-combined_plain.pdf.]

Fishman, M.J., and Friedman, L.C., eds., 1989, Methods for determination of inorganic substances in water and fluvial sediments: U.S. Geological Survey Techniques of WaterResources Investigations, book 5, chap. A1, 545 p. [Also available at https://pubs.er.usgs.gov/publication/twri05A1.]

Fishman, M.J., ed., 1993, Methods of analysis by the U.S. Geological Survey national water quality laboratoryDetermination of inorganic and organic constituents in water and fluvial sediments: U.S. Geological Survey Open-File Report 93-125, 217 p. [Also available at https://pubs.er.usgs.gov/publication/ofr93125.]

Graham, J.L., Stone, M.L., Rasmussen, T.J., and Poulton, B.C., 2010, Effects of wastewater effluent discharge and treatment facility upgrades on environmental and biological conditions of the Upper Blue River, Johnson County, Kansas and Jackson County, Missouri, January 2003 through March 2009: U.S. Geological Survey Scientific Investigations Report 2010-5248, 85 p. [Also available at https://pubs.er.usgs.gov/publication/sir20105248.]

Graham, J.L., Stone, M.L., Rasmussen, T.J., Foster, G.M., Poulton, B.C., Paxson, C.R., and Harris, T.D., 2014, Effects of wastewater effluent discharge and treatment facility upgrades on environmental and biological conditions of Indian Creek, Johnson County, Kansas, June 2004 through June 2013: U.S. Geological Survey Scientific Investigations Report 2014-5187, 78 p., appendixes. [Also available at https://doi.org/10.3133/sir20145187.]

Gray, J.R., Glysson, G.D., Turcios, L.M., and Schwarz, G.E., 2000, Comparability of suspended-sediment concentration and total suspended solids data: U.S. Geological Survey Water-Resources Investigations Report 2000-4191, 14 p. [Also available at https://pubs.er.usgs.gov/publication/ wri004191.]

Guy, H.P., 1969, Laboratory theory and methods for sediment analysis: U.S. Geological Survey Techniques of WaterResources Investigations, book 5, chap. C1, 58 p. [Also available at https://pubs.er.usgs.gov/publication/twri05C1.] 
Helsel, D.R., and Hirsch, R.M., 2002, Statistical methods in water resources-Hydrologic analysis and interpretation (ver. 1.1, September 2002): U.S. Geological Survey Techniques of Water-Resources Investigations, book 4, chap. A3, 510 p. [Also available at https://pubs.er.usgs.gov/ publication/twri04A3.]

Kansas Department of Health and Environment, 2012, Kansas 303(d) list of impaired waters, public hearing information and methodology: Kansas Department of Health and Environment web page, accessed April 2014 at http://www.kdheks.gov/tmdl/methodology.htm.

Kansas Department of Health and Environment, 2013, National pollutant discharge elimination system general permit for discharges of storm water from small municipal separate storm sewer systems (MS4s): Kansas Department of Health and Environment fact sheet, 3 p., accessed April 2014 at http://www.kdheks.gov/muni/download/stormwater/ attachment_3_stormwater_ms4_reissue_fact_sheet.pdf.

Kansas Department of Health and Environment, 2014, TMDLs for the Kansas Lower Republican River Basin: Kansas Department of Health and Environment web page, accessed October 2014 at http://www.kdheks.gov/tmdl/ krtmdl.htm\#Table1.

Kansas Department of Health and Environment, 2016a, The basics of TMDLs: Kansas Department of Health and Environment web page, accessed December 2016 at http://www.kdheks.gov/tmdl/basic.htm.

Kansas Department of Health and Environment, 2016b, Municipal stormwater program: Kansas Department of Health and Environment web page, accessed September 14, 2016, at http://www.kdheks.gov/muni/ms4.htm.

King, L.R., Rasmussen, T.J., and Paxson, C.R., 2017, Waterquality data for base flow and storm runoff samples collected in Johnson County, Kansas, from January 2015 through June 2016: U.S. Geological Survey data release, accessed August 21, 2017, at https://doi.org/10.5066/ F7GT5M2G.

Lee, C.J., and Ziegler, A.C., 2010, Effects of urbanization, construction activity, management practices, and impoundments on suspended-sediment transport in Johnson County, northeast Kansas, February 2006 through November 2008: U.S. Geological Survey Scientific Investigations Report 2010-5128, 54 p. [Also available at https://pubs.er.usgs.gov/publication/sir20105128.]

Lee, C.J., Mau, D.P., and Rasmussen, T.J., 2005, Effects of nonpoint and selected point contaminant sources on stream-water quality and relation to land use in Johnson County, northeastern Kansas, October 2002 through June 2004: U.S. Geological Survey Scientific Investigations Report 2005-5144, 104 p. [Also available at https://pubs.er.usgs.gov/publication/sir20055144.]
Lee, C.J., Rasmussen, P.P., Ziegler, A.C., and Fuller, C.C., 2008, Transport and sources of suspended sediment in the Mill Creek watershed, Johnson County, northeast Kansas, 2006-07: U.S. Geological Survey Scientific Investigations Report 2009-5001, 52 p. [Also available at https://pubs.er.usgs.gov/publication/sir20095001.]

Moody, J.A., 1993, Evaluation of the Lagrangian scheme for sampling the Mississippi River during 1987-90: U.S. Geological Survey Water-Resources Investigations Report 1993-4042, 31 p. [Also available at https://pubs.er.usgs.gov/publication/wri934042.]

Myers, D.N., Stoeckel, D.M., Bushon, R.N., Francy, D.S., and Brady, A.M.G., 2014, Fecal indicator bacteria (ver. 2.1), sec. 7.1 of Myers, D.N., and Wilde, F.D., eds., Biological indicators: U.S. Geological Survey Techniques of WaterResources Investigations, book 9, chap. A7, 73 p. [Also available at https://pubs.er.usgs.gov/publication/twri09A7].

Overland Park, 2017, StormWatch alert flood warning system: Overland Park web interface, accessed March 3, 2017, at https://www.stormwatch.com/home.php.

Painter, C.C., and Loving, B.L., 2015, U.S. Geological Survey quality-assurance plan for surface-water activities in Kansas, 2015: U.S. Geological Survey Open-File Report 2015-1074, 33 p., accessed June 23, 2017, at https://doi.org/10.3133/ofr20151074.

Patton, C.J., and Kryskalla, J.R., 2011, Colorimetric determination of nitrate plus nitrite in water by enzymatic reduction, automated discrete analyzer methods: U.S. Geological Survey Techniques and Methods, book 5, chap. B8, 34 p. [Also available at https://pubs.er.usgs.gov/publication/ tm5B8.]

Patton, C.J., and Truitt, E.P., 1992, Methods of analysis by the U.S. Geological Survey National Water Quality Laboratory-Determination of total phosphorus by a Kjeldahl digestion method and an automated colorimetric finish that includes dialysis: U.S. Geological Survey Open-File Report 1992-0146, 39 p. [Also available at https://pubs.er.usgs.gov/publication/ofr92146.]

Patton, C.J., and Truitt, E.P., 2000, Methods of analysis by the U.S. Geological Survey National Water Quality Laboratory-Determination of ammonium plus organic nitrogen by a Kjeldahl digestion method and an automated photometric finish that includes digest cleanup by gas diffusion: U.S. Geological Survey Open-File Report 2000-0170, 31 p. [Also available at https://pubs.er.usgs.gov/publication/ ofr00170.]

Paul, M.J., and Meyer, J.L., 2001, Streams in the urban landscape: Annual Review of Ecology and Systematics, v. 32, p. 333-365. [Also available at https://doi.org/10.1146/ annurev.ecolsys.32.081501.114040.] 
Pellerin, B.A., Bergamaschi, B.A., Downing, B.D., Saraceno, J.F., Garrett, J.A., and Olsen, L.D., 2013, Optical techniques for the determination of nitrate in environmental watersGuidelines for instrument selection, operation, deployment, maintenance, quality assurance, and data reporting: U.S. Geological Survey Techniques and Methods, book 1, chap. D5, 37 p. [Also available at https://pubs.er.usgs.gov/ publication/tm1D5.]

Rasmussen, T.J., and Gatotho, Jackline, 2014, Water-quality variability and constituent transport and processes in streams of Johnson County, Kansas, using continuous monitoring and regression models, 2003-11: U.S. Geological Survey Scientific Investigations Report 2013-5221, 53 p., accessed June 2016 at https://doi.org/10.3133/sir20135221.

Rasmussen, T.J., Bennett, T.J., Stone, M.L., Foster, G.M., Graham, J.L., and Putnam, J.E., 2014, Quality-assurance and data-management plan for water-quality activities in the Kansas Water Science Center, 2014: U.S. Geological Survey Open-File Report 2014-1233, 41 p., accessed June 2016 at https://doi.org/10.3133/ofr20141233.]

Rasmussen, T.J., Lee, C.J., and Ziegler, A.C., 2008, Estimation of constituent concentrations, loads, and yields in streams of Johnson County, northeast Kansas, using continuous waterquality monitoring and regression models, October 2002 through December 2006: U.S. Geological Survey Scientific Investigations Report 2008-5014, 103 p. [Also available at https://pubs.er.usgs.gov/publication/sir20085014.]

Rasmussen, T.J., Stone, M.S., Poulton, B.C., and Graham, J.L., 2012, Quality of streams in Johnson County, Kansas, 2002-10: U.S. Geological Survey Scientific Investigations Report 2012-5279, 103 p., accessed June 2016 at https://pubs.er.usgs.gov/publication/sir20125279.

Seaber, P.R., Kapinos, F.P., and Knapp, G.L., 1987, Hydrologic unit maps: U.S. Geological Survey WaterSupply Paper 2294, 63 p., 1 pl. [Also available at https://pubs.er.usgs.gov/publication/wsp2294.]

The NELAC Institute, 2016, TNI standards: The NELAC Institute web page, accessed July 31, 2017, at http://www.nelac-institute.org/content/CSDP/standards.php.

Turnipseed, D.P., and Sauer, V.B., 2010, Discharge measurements at gaging stations: U.S. Geological Survey Techniques and Methods, book 3, chap. A8, 87 p. [Also available at https://pubs.er.usgs.gov/publication/tm3A8.]
U.S. Department of Agriculture, 2003, National water quality handbook: Washington, D.C., U.S. Department of Agriculture, Natural Resources Conservation Service, [variously paged]. [Also available at https://www.nrcs.usda.gov/ Internet/FSE_DOCUMENTS/stelprdb1044775.pdf.]

U.S. Geological Survey, [variously dated], National field manual for the collection of water-quality data: U.S. Geological Survey Techniques of Water-Resources Investigations, book 9, chaps. A1-A10, [variously paged], accessed June 23, 2016, at https://pubs.water.usgs.gov/twri9A.

U.S. Geological Survey, 2006, Collection of water samples (ver. 2.0, September 2006): U.S. Geological Survey Techniques of Water-Resources Investigations, book 9, chap. A4, accessed January 29, 2016, at http://pubs.water.usgs.gov/ twri9A4/.

U.S. Geological Survey, 2016a, Kansas real-time water quality: U.S. Geological Survey web interface, accessed December 2, 2016, at https://nrtwq.usgs.gov/ks/.

U.S. Geological Survey, 2016b, USGS water data for the Nation: U.S. Geological Survey National Water Information System database, accessed December 16, 2016, at https://doi.org/10.5066/F7P55KJN.

U.S. Geological Survey, [undated], The branch of quality systems: U.S. Geological Survey web page, accessed July 23, 2017, at https://bqs.usgs.gov/.

Wagner, R.J., Boulger, R.W., Jr., Oblinger, C.J., and Smith, B.A., 2006, Guidelines and standard procedures for continuous water-quality monitors - Station operation, record computation, and data reporting: U.S. Geological Survey Techniques and Methods, book 1, chap. D3, [variously paged]. [Also available at https://pubs.er.usgs.gov/ publication/tm1D3.]

Wilkison, D.H., Armstrong, D.J., and Hampton, S.A., 2009, Character and trends of water quality in the Blue River Basin, Kansas City metropolitan area, Missouri and Kansas, 1998 through 2007: U.S. Geological Survey Scientific Investigations Report 2009-5169, 211 p. [Also available at https://pubs.er.usgs.gov/publication/sir20095169.]

YSI Inc., 2014, EXO user manual—Advanced water quality monitoring platform (rev. E): Yellow Springs, Ohio, YSI Inc., 156 p. [Also available at https://www.ysi.com/File\%20 Library/Documents/Manuals/EXO-User-Manual-Web.pdf.] 
For additional information concerning this publication, contact: Director, Kansas Water Science Center

U.S. Geological Survey

4821 Quail Crest Place

Lawrence, KS 66049

(785) 842-9909

Or visit the Kansas Water Science Center website at https://ks.water.usgs.gov

Publishing support provided by the

Rolla and Pembroke Publishing Service Centers 

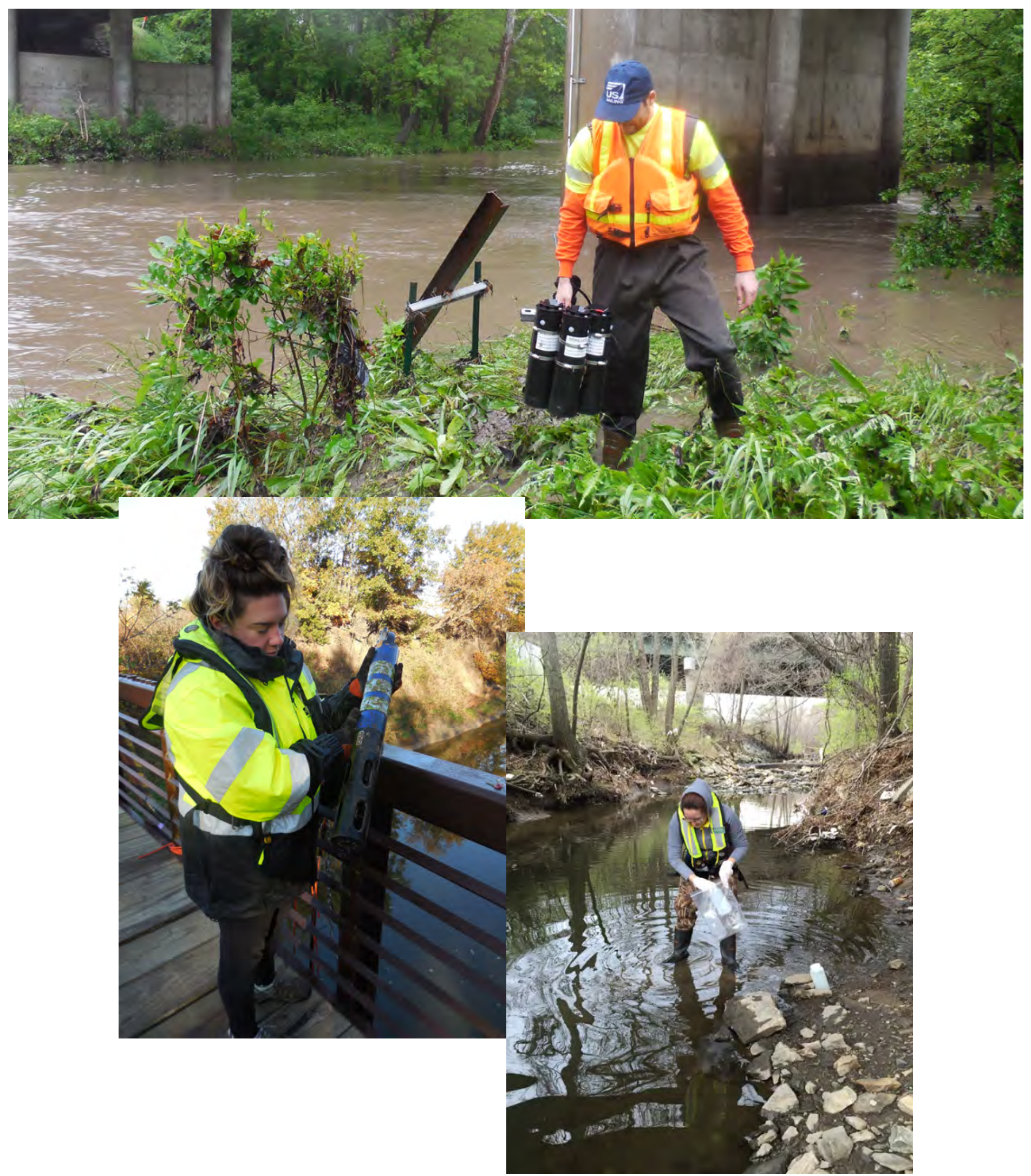